\title{
Current computer-aided drug design methodologies in discovery of novel drug candidates for neuropsychiatric and inflammatory diseases
}

\section{Milica Radan, Jelena Bošković, Vladimir Dobričić, Olivera Čudina, and Katarina Nikolić*}

\author{
University of Belgrade - Faculty of Pharmacy, Department of Pharmaceutical \\ Chemistry, Vojvode Stepe 450, 11000 Belgrade, Serbia
}

*Corresponding author: Katarina Nikolic, e-mail: knikolic@pharmacy.bg.ac.rs

\begin{abstract}
Drug discovery and development is a very challenging, expensive and time-consuming process. Impressive technological advances in computer sciences and molecular biology have made it possible to use computer-aided drug design (CADD) methods in various stages of the drug discovery and development pipeline. Nowadays, CADD presents an efficacious and indispensable tool, widely used in medicinal chemistry, to lead rational drug design and synthesis of novel compounds. In this article, an overview of commonly used CADD approaches from hit identification to lead optimization was presented. Moreover, different aspects of design of multitarget ligands for neuropsychiatric and anti-inflammatory diseases were summarized. Apparently, designing multi-target directed ligands for treatment of various complex diseases may offer better efficacy, and fewer side effects. Antipsychotics that act through aminergic G protein-coupled receptors (GPCRs), especially dopamine $\mathrm{D}_{2}$ and serotonin 5-HT $\mathrm{HT}_{2 \mathrm{~A}}$ receptors, are the best option for treatment of various symptoms associated with neuropsychiatric disorders. Furthermore, multi-target directed cyclooxygenase-2 (COX-2) and 5-lipoxygenase (5-LOX) inhibitors are also a successful approach to aid the discovery of new anti-inflammatory drugs with fewer side effects. Overall, employing CADD approaches in the process of rational drug design provides a great opportunity for future development, allowing rapid identification of compounds with the optimal polypharmacological profile.
\end{abstract}

Keywords: CADD, 5-HT2A, D2, COX-2, 5-LOX 


\section{Introduction}

The process of drug discovery and development requires a lot of effort, time and costs. On average, it is assessed that getting a drug into the market takes 10-15 years and costs $\$ 2.6$ billion (1). Therefore, there is a great need to accelerate the drug discovery process to find new therapeutics, as well as discovery methodologies. During this process, intensive research has to be done to find good drug candidates that will successfully get into preclinical and clinical trials (2). There are several main steps that are carried out during drug discovery. The first one is to identify and validate potential targets for a specific disease (3). After that, the next step is the identification of lead compound - a promising molecule which exhibits the desired biological or pharmacological activity. Subsequently, lead compounds selected from initial screening are then optimized to improve their potency, physicochemical and pharmacokinetic properties, as well as to reduce side effects $(3,4)$.

In recent years, computer-aided drug design (CADD) has become increasingly important in the process of drug discovery and development (Figure 1) (5-8).

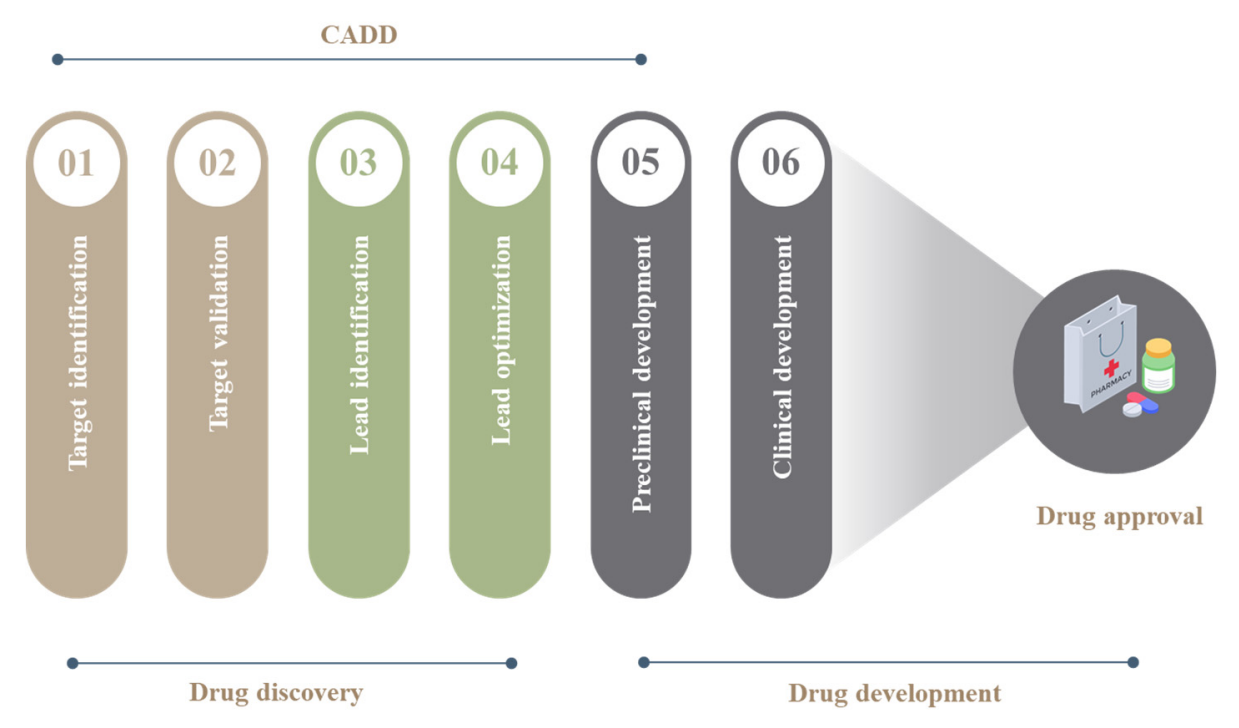

Figure 1. The position of CADD in the drug discovery and development pipeline Slika 1. Pozicija CADD u procesu otkrića lekova

It is based on different in silico methods that are used to facilitate rational drug design and synthesis of novel compounds. The application of these methods in early phases of research may reduce the number of experiments that need to be performed, but also enable the handling of a huge amount of data, which are beyond human analytical skills (9). Moreover, the utilization of CADD techniques to identify hits and select the best candidates for further evaluation will greatly decrease time and resource requirements of chemical synthesis and biological testing (10). Different computational methods need to be integrated properly to achieve a comprehensive study, as well as 
accurate and effective rational drug design, and thereby to eliminate key risks before making an expensive investment at a late stage $(1,11)$. Thus, the use of CADD for three main purposes has become a standard practice in modern drug design: (1) filter huge data libraries to select compounds that can be examined experimentally; (2) guide the lead optimization to increase its affinity or optimize physicochemical and pharmacokinetic properties; (3) rational drug design of novel compounds (9).

The introduction of CADD approaches in rational design of potent therapeutics has led to the improved overall efficiency of drug discovery, as well as reduced development times to only 6-8 years (12).

\section{CADD methods in drug design}

Depending on the available information about a particular target and ligands, it is possible to utilize different CADD strategies that can be categorized into two groups: structure-based drug design (SBDD) and ligand-based drug design (LBDD) methods (9, 13). Generally, structure-based CADD methods require the 3D structure of the target of interest, and are most commonly used to identify key sites and binding interactions. However, ligand-based CADD approaches are usually based on the study of the structureactivity relationship and are used in the absence of structural information about the target of interest (14). In particular, CADD methods are rapidly improving and new approaches are frequently developing, challenging researchers to be continually updated on the latest knowledge (15). In this review, commonly used CADD methods (Figure 2) will be presented, focusing on those used in our lab for the design of novel anti-inflammatory agents, as well as aminergic GPCR ligands for the treatment of neuropsychiatric disorders.

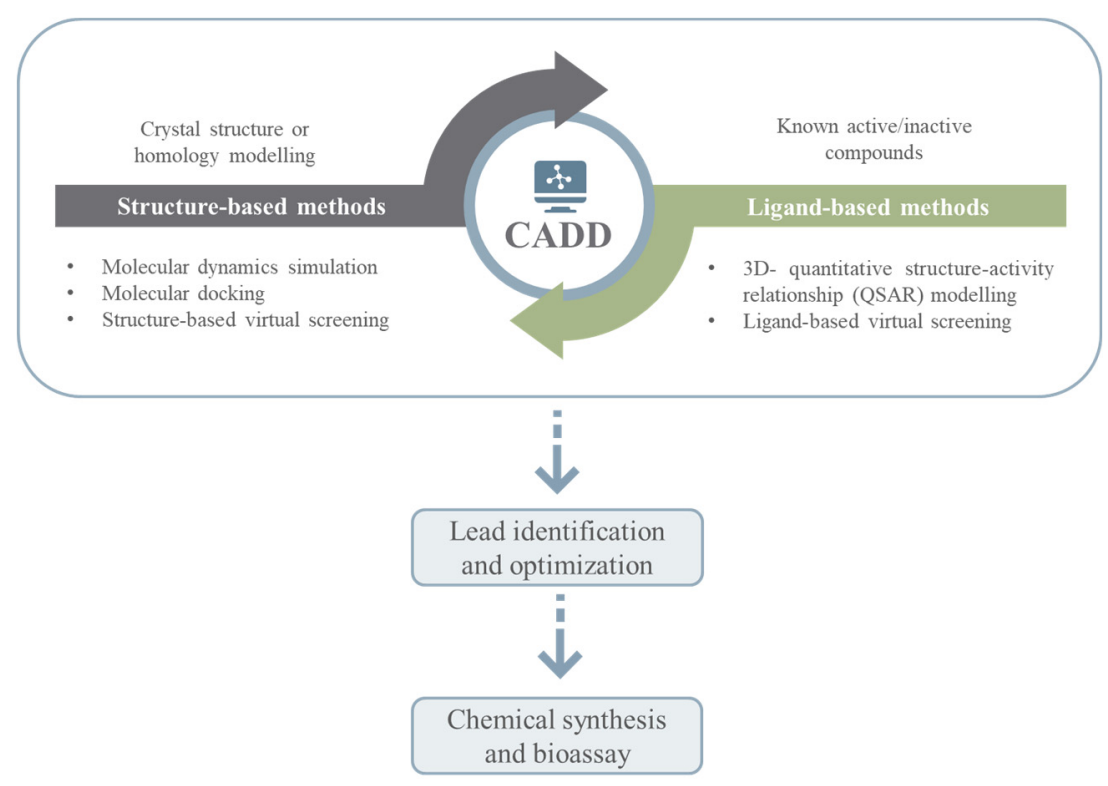

Figure 2. A summary of commonly used CADD methods

Slika 2. Prikaz najčešće korišćenih CADD metoda 


\section{Structure-based drug design methods}

SBDD methods use the known 3D protein structure to assist in the process of rational drug design. Great advances in nuclear magnetic resonance (NMR) techniques and X-ray crystallography have led to the discovery of more than $150,0003 \mathrm{D}$ protein structures available in databases such as Protein Data Bank (PDB) $(16,17)$. Despite certain limitations, the availability of a large number of solved protein structures enables deeper insights into the ligand and protein complex including analysis of binding conformations, characterization of key intermolecular interactions, as well as identification of unknown binding sites (18). Nevertheless, if the 3D structure of the target of interest is not yet solved, homology modelling is the most reliable method for its prediction. The structure of the known homologous protein is used to generate the 3D structure of protein of interest from a related amino acid sequence. Once the structure is built, the Ramachandran plot is most commonly used for model validation (19). Programs such as MODELLER (20) and an on-line web server such as SWISS-MODEL (21) are the most frequently used for high quality protein structure predictions (22).

Therefore, SBDD methods are widely used for molecular modifications with the aim of improving interactions in the binding site of the target protein and increasing the affinity of new ligands. The most frequently used structure-based methods in the drug discovery process of new drugs are molecular dynamics (MD), molecular docking, and structure-based virtual screening (SBVS) (16).

\section{Molecular dynamics}

It is well known that the protein-ligand interactions are followed by significant conformational changes of both molecules. MD simulation is a widely used method for studying the motions of atoms and molecules, providing valuable insights into structure and dynamics (23). It allows a deeper analysis of the protein-ligand interactions over a period of time, in order to reproduce the actual behaviour of all the atoms in a biomolecular system, taking into account the flexibility of structures and the effects of solvents (24). Once the forces exerted on each atom have been calculated, the principles of Newton's laws of motion are used to predict the position of these atoms as a function of time $(24,25)$. Molecular interaction potentials, which are typically parameterized by quantum chemical calculations combined with experimental data, are used to define the atomic forces that modulate molecular movement $(25,26)$. These parameters, called the force-field, describe the influence of bonded or non-bonded interactions to the general function $(27,28)$. Considering the large number of calculations that are required, MD simulations need high performance computing resources, such as multiple GPU based PCs, cluster computing resources or supercomputers, depending on the MD system setup. In addition, if computational resources are limited, in some cases they can be saved by employing the implicit solvent model instead of explicit as it was show to be computationally faster for small systems (29). Although systems without a solvent are inexpensive, they are not realistic, since the solvent plays an important role in protein structure determination. Finally, the obtained trajectory describes the atomic-level 
configuration of the simulated system at every point in time, which presents a particular challenge for experimental methods. MD simulations provide valuable information for studying various functional processes such as: conformational changes, ligand binding, or membrane transport. Moreover, they are likely to play an increasingly important role in the lead optimization. Several programmes for MD simulation are available, such as: AMBER (30), CHARMM (31), GROMACS (32), and NAMD (33).

\section{Molecular docking}

Molecular docking is a frequently used CADD technique for the analysis of ligandprotein interactions. Starting from the high-resolution X-ray, NMR or homologymodelled structure, it aims to predict the predominant binding mode (conformation/orientation i.e., poses) and free binding energy of small molecules (34, 35). Molecular docking consists of two basic components: sampling algorithm to explore conformations and scoring function to rank each predicted pose (36). There are two major categories of sampling algorithms, systematic and stochastic (37). Scoring functions are used not only to identify the binding pose but also to rank obtained conformations. Additionally, they estimate complex binding energy and can be classified into empirical, force field based, or knowledge based (38). Generally, there are three ways of docking small molecules into the protein structure: (1) rigid docking, where both ligand and protein are treated as rigid, (2) flexible-rigid docking is widely used method where protein conformation is fixed, while the ligand is considered to be flexible, and (3) flexible docking, where conformations of both the ligand and protein are flexible, which is more accurate but challenging (39). Ideally, the obtained results should be in concordance with the experimental binding mode, which could be validated with root mean square deviation (RMSD) (40). Results obtained through a successful molecular docking study can be employed for virtual screening (VS) on large libraries of compounds, structure-activity relationship analysis, or lead optimization. Over the last decades, a large number of programmes for molecular docking have been developed, while the most frequently used ones are AutoDock (41), AutoDock Vina (42), GOLD (43), and GLIDE (44) from the Schrödinger suite $(45,46)$.

\section{Virtual screening}

Virtual screening is a computational method widely applied in the early stages of the drug discovery process. Generally, it is an essential tool for the screening of small molecule libraries in order to identify lead-like compounds with potential biological activity against a target of interest (47). VS techniques can be categorized into two major groups: ligand-based virtual screening (LBVS) and structure-based virtual screening (SBVS). LBVS is mainly used in cases where the 3D structure of the target is unknown. This method relies on a comparison of the chemical structures (similarity search), pharmacophoric features (pharmacophore mapping) or molecular descriptors of the known compounds to those from scanned databases $(48,49)$. Essentially, it is based on the theory that similar compounds possess a similar behaviour. For the second group of 
VS - SBVS, protein 3D structure is the main requirement. This approach involves the docking of each ligand from a database into the protein binding site. Subsequently, the scoring function ranks the selected ligands based on their affinity for the target $(49,50)$. Therefore, VS makes significant contributions to processes of drug discovery, in particular in hit identification and lead optimization (51).

\section{Ligand-based drug design methods}

Ligand-based methods or indirect methods are generally used when the structure of the selected target is unidentified. In this case, the rational design of new compounds is based on the study of $2 \mathrm{D}$ or $3 \mathrm{D}$ structures of ligands known to interact with a target of interest. One of the commonly employed LBDD techniques is the quantitative structureactivity relationship (QSAR) approach that predicts biological activity from chemical structures (9). In general, it is based on the assumption that compounds with common structures also have similar physicochemical properties and consequently have similar binding modes (52).

\section{Quantitative structure-activity relationship}

QSAR modelling is one of the major computational methods, used in medical chemistry for more than 50 years (53). It is based on statistics that form an empirical relationship between the structural features of studied compounds and their experimentally determined biological activity (52). The general workflow of QSAR modelling can be divided into three phases: the first is to collect a group of examined ligands and to calculate molecular descriptors that affect biological activity, then model building, and finally model validation (54). 2D-QSAR and 3D-QSAR are the most common approaches for model building. The first method considers the geometrical and topological properties but excludes $3 \mathrm{D}$ conformation of the compound. On the other hand, 3D-QSAR method focuses on the spatial properties of the compound, which may be crucial for distinguishing stereoisomers (55). Nevertheless, the representation of the molecular structure by calculated physicochemical and 3D structural descriptors is a critical step for the further model development for predicting small molecule-receptor interactions (56). Statistical methods are employed to select the most important molecular descriptors, as well as to gain further insights into the key structural features $(53,54)$. Subsequently, different internal and external validation methods can be utilized to confirm the predictive power and stability of the created QSAR model (57). Finally, the model can be used to modify existing compounds and improve their activities, as well as to predict the activity of newly designed compounds. Therefore, 3D-QSAR is a powerful tool for establishing the relationship between the structure and activity of examined compounds, but it can also be used for database screening to find new active molecules $(10,15)$. 


\section{In silico ADMET (absorption, distribution, metabolism, excretion, toxicity) prediction}

In silico ADMET profiling of compounds is one of the most significant steps in the process of drug discovery (58). Having early information on pharmacokinetic properties, metabolism and potential toxicity is crucial in order to avoid the risk of late-stage failures, as well as to guide the lead optimisation by increasing its drug-like properties. Moreover, ADMET data may be analysed by building predictive QSAR models to search for correlations between the activity and a wide variety of ADMET descriptors (58-60). Currently, there are many commercially available as well as free-to-use programmes that can be used for in silico ADMET profiling, such as: Swiss-ADME (61), ADMET Predictor (62), Schrodinger-QikProp (63) and many others $(58,59)$.

\section{Successful application of CADD approaches in the discovery of aminergic GPCR ligands for treatment of neuropsychiatric disorders}

GPCRs are the most frequently studied receptors for the discovery of new ligands. A number of successful examples of the application of CADD strategies have been reported in the area of aminergic GPCRs. These receptors belong to rhodopsin like GPCRs, class A, and they are targets for $25 \%$ of current drugs (64). In this review, an upto-date summary of the CADD approaches used in discovery of ligands binding to a specific subfamily of aminergic GPCRs, namely dopamine and serotonin receptor family was provided. Both receptors play an essential role in physiology and pathophysiology of various brain disorders, including depression, schizophrenia, anxiety, Parkinson's disease and many others (65-68). Atypical antipsychotics, generally known as antagonists of dopamine $\mathrm{D}_{2}$ and serotonin $5-\mathrm{HT}_{2} \mathrm{~A}$ receptors are used to alleviate the symptoms associated with these conditions (69-71). However, for an effective treatment, a balanced modulation of these receptors and specific activity and selectivity profile of the drug is crucial. Therefore, research and development of new antipsychotics with good efficacy, selectivity, and reduced side effects may present a significant advance in the therapy of neuropsychiatric disorders.

Among all, the aminergic GPCR subfamily is the most extensively studied and many high-resolution crystal structures are available $(17,72)$. Today, the GPCR database (GPCRdb, http://gpcrdb.org) provides detailed information about the sequence, mutations and structures of GPCRs which could be valuable for various types of analyses (72). The combination of structural analyses with the information of QSAR studies may provide complementary research to gain a deeper insight into the knowledge of receptor-ligand complexes (73-75).

Serotonin 5-HT2A and dopamine $\mathrm{D}_{2}$ receptors are among the most attractive therapeutic targets for different brain disorders. As mentioned above, structural information is required to gain insights into protein activities, as well as for SBDD study. Many studies have been performed using the homology modelling method to create 3D structures of 5-HT2 $\mathrm{HT}_{2}$ and $\mathrm{D}_{2}$ receptors until their crystal structures were solved $(76,77)$. 
Recently, several high-resolution 3D structures of these receptors complexed with the agonist, inverse agonist or antagonist have been generated (Table I) (78-84). In a relevant number of articles described below, different CADD approaches were successfully employed in order to rationally design novel promising compounds for selected receptors.

Table I Crystal structures of 5- $\mathrm{HT}_{2 \mathrm{~A}}$ and $\mathrm{D}_{2}$ receptors from GPCRdb

Tabela I Kristalne strukture 5- $\mathrm{HT}_{2 \mathrm{~A}}$ i $\mathrm{D}_{2}$ receptora preuzete iz GPCRdb

\begin{tabular}{|c|l|l|l|l|l|c|}
\hline \multirow{4}{*}{$\mathbf{5 - H T}_{2 \mathbf{}}$} & PDB ID & State & Resolution & \multicolumn{1}{|c|}{ Ligand name } & Function & Reference \\
\cline { 2 - 7 } & $6 \mathrm{WHA}$ & Active & 3.40 & $25-\mathrm{CN}-\mathrm{NBOH}$ & Agonist & $(78)$ \\
\cline { 2 - 7 } receptor & $6 \mathrm{WGT}$ & Inactive & 3.40 & Lysergide & Agonist & $(78)$ \\
\cline { 2 - 7 } & $6 \mathrm{WH} 4$ & Inactive & 3.40 & CHEMBL428892 & Inverse agonist & $(78)$ \\
\cline { 2 - 7 } & $6 \mathrm{~A} 94$ & Inactive & 2.90 & Zotepine & Antagonist & $(79)$ \\
\cline { 2 - 7 } & $6 \mathrm{~A} 93$ & Inactive & 3.00 & Risperidone & Antagonist & $(79)$ \\
\hline \multirow{4}{*}{ D $_{\mathbf{2}}^{\text {receptor }}$} & $7 \mathrm{JVR}$ & Active & 2.80 & Bromocriptine & Agonist & $(80)$ \\
\cline { 2 - 7 } & $7 \mathrm{DFP}$ & Inactive & 3.10 & Spiperone & Antagonist & $(81)$ \\
\cline { 2 - 7 } & $6 \mathrm{VMS}$ & Active & 3.80 & Bromocriptine & Agonist & $(82)$ \\
\cline { 2 - 7 } & $6 \mathrm{LUQ}$ & Inactive & 3.10 & Haloperidol & Antagonist & $(83)$ \\
\cline { 2 - 7 } & $6 \mathrm{CM} 4$ & Inactive & 2.90 & Risperidone & Inverse agonist & $(84)$ \\
\hline
\end{tabular}

In 2017, Lin et al. examined arylpiperazine derivatives as promising 5- $\mathrm{HT}_{2} \mathrm{~A}$ receptor antagonists by an integrated use of 3D-QSAR analysis, molecular docking and MD simulation (85). Firstly, they employed comparative molecular field analyses (CoMFA) and comparative molecular similarity indices analyses (CoMSIA) in a 3DQSAR study to select the most important structural features that affect their biological activity (85). Even though CoMFA/CoMSIA methods are frequently used in 3D-QSAR modelling, they are largely dependent on the structure alignment, which presents their main limitation. Besides, molecular docking (using GOLD software) followed with MD simulation (using GROMACS software) was used to analyse the binding mode of the examined ligands to the 5- $\mathrm{HT}_{2 \mathrm{~A}}$ receptor. The obtained results revealed that $\mathrm{H}$-bonds with D3.32 and S3.36, two $\pi-\pi$ stacking interactions with W3.28 and F6.52, and hydrophobic interaction are the most important for high-affinity binding. Lastly, using compound 1 (13) from Figure 3 as a template, new potential arylpiperazine antagonists were designed based on the obtained results. 


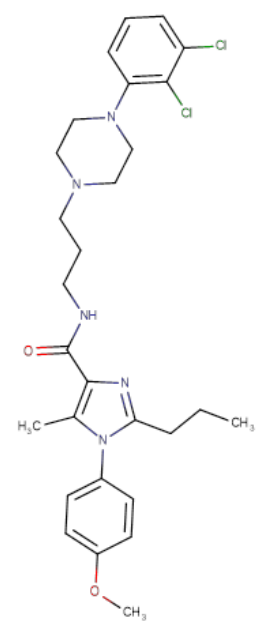

1-(13)
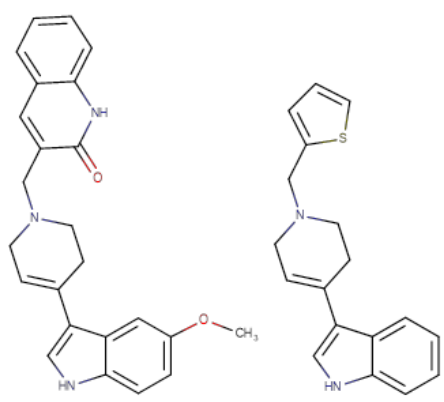

2-(D2AAK1)

3-(5)
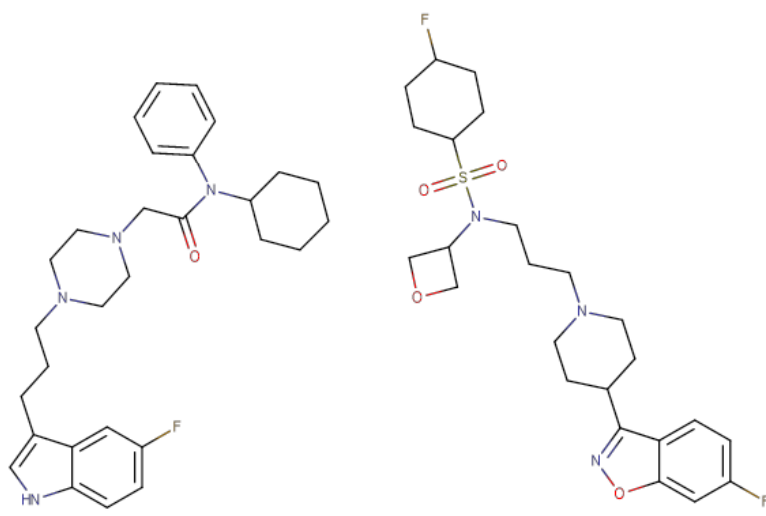

7-(9f)

5-(5.4)
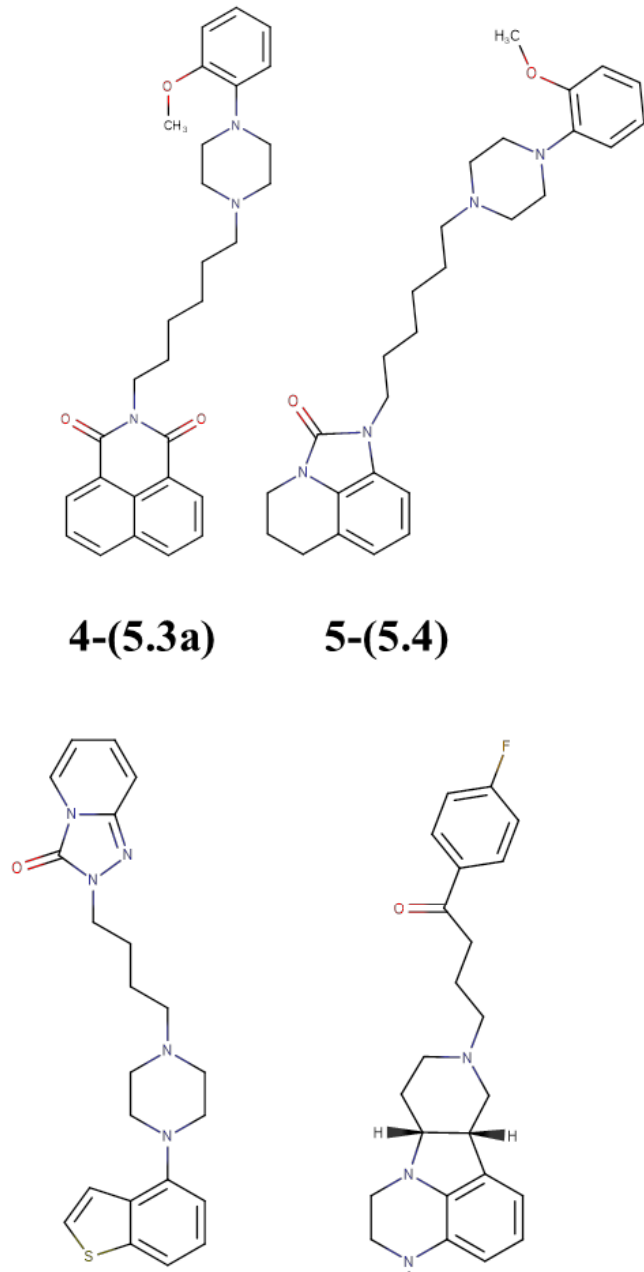

4-(5.3a)

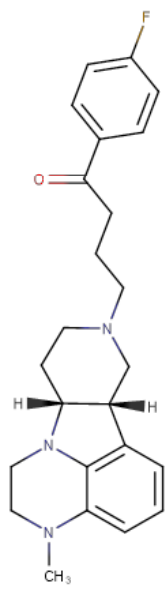

8-(S1)

Lumateperone

6-(FW01)

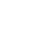<smiles>OCCC1OCCc2ccsc21</smiles>

SEP-363856

Figure 3. Structures of novel multi-target antipsychotics adopted from references $85(1), 90(2), 93(3), 100(4,5), 102(6,7), 104(8), 105$ (Lumateperon) and 106 (SEP-363856)

Slika 3. Strukture novih višeciljnih antipsihotika preuzete iz referenci 85 (1), 90 (2), 93 (3), $100(4,5), 102(6,7), 104(8), 105$ (Lumateperon) and 106 (SEP-363856) 
More recently, a similar procedure was used to design potent dual antagonists of $\mathrm{D}_{2}$ and 5-HT2A receptors (86). Zhang et al. used structures of ziprasidone, risperidone, and brexpiprazole to design novel pyridopyrimidinone derivatives (86). In this study, CoMFA, CoMSIA, Topomer CoMFA and HQSAR (hologram quantitative structure activity relationship) models were successfully built and used for further visualization. The obtained results revealed that the modification of region A with bulkier substituents may decrease the activity of studied antagonists, while the introduction of nitrogen atom at position b may lead to an increase in the activity (Figure 4) (86). Afterwards, a molecular docking study performed with SYBYL-X software was used to validate the created models (87). In summary, it demonstrated that the salt bridge with Asp residue (D3.32), as well as hydrogen bonding, Van der Waals, and hydrophobic interactions maintain the stability of both complexes. Additionally, pharmacophore-based VS model was used to search the ZINC12 database to find out new dual antagonists by using the UNITY Flex program (88). Selected compounds were docked into $\mathrm{D}_{2}$ and 5-HT2A receptors, and four of them were chosen for further optimization. MD simulation was also used to confirm obtained docking results. In conclusion, combining LBVS and molecular docking, as well as 3D-QSAR approach with SBDD methods presents a promising tool for future rational drug design of new compounds and creating new opportunities for innovation in medicinal chemistry.

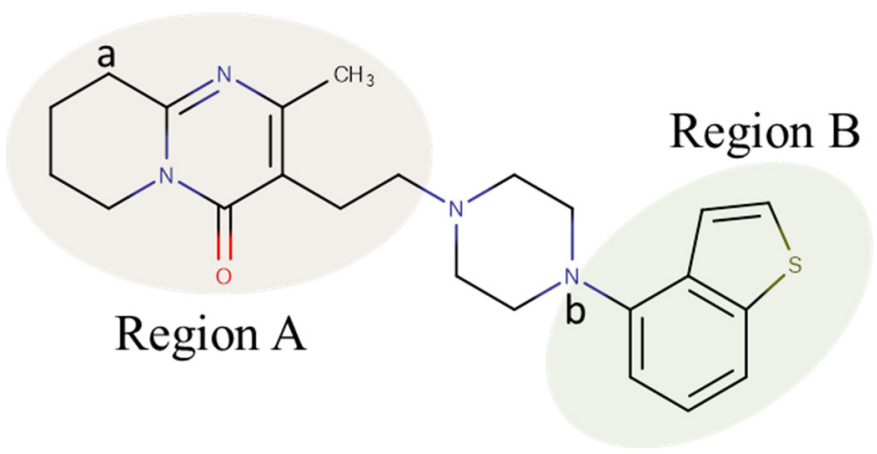

Figure 4. General structure of compounds used in Zhang et al. study (86)

Slika 4. Opšta struktura jedinjenja proučavanih u studiji objavljenoj od strane Zhang et al. (86)

Kumar et al. also employed LBVS to create a new library of 5-HT2A receptor antagonists using 2D/3D similarity search of ZINC database (InstJChem and Screen3D softwares, ChemAxon Ltd., Budapest, Hungary) (89). All the selected ligands were docked into a 5- $\mathrm{HT}_{2 \mathrm{~A}}$ receptor, using GOLD software, whereas MD simulations (GROMACS software) were used to verify the stability of the formed complexes.

Moreover, a group of novel potential antipsychotics was identified through a VS approach. Kaczor et al. successfully implemented SBVS of the Enamine compound 
database to find dopamine $\mathrm{D}_{2}$ receptor ligands (90). Multistep VS workflow from the Schrodinger software suite was used for hits docking (91). As a result, 21 compounds were selected as the best candidates for further experimental validation. Ten molecules were identified that have an additional affinity for the 5- $\mathrm{HT}_{2 \mathrm{~A}}$ receptor, which made them good starting points for further optimization studies. Compound 2 (D2AAK1) was selected as the most promising compound from this VS study (Figure 3). Additional in silico, in vitro and in vivo studies confirmed that D2AAK1 is a multi-target ligand of aminergic GPCRs, with neuroprotective properties and pro-cognitive activity, therefore providing a new therapeutic option for the treatment of multifactorial brain disorders (9294). Since in vitro studies showed the affinity of D2AAK1 for dopamine $\mathrm{D}_{1}$ and $\mathrm{D}_{3}$ receptors, as well as for serotonin $5-\mathrm{HT}_{1 \mathrm{~A}}$ and $5-\mathrm{HT}_{2} \mathrm{~A}$ receptors, molecular dynamics (using Desmond) and molecular docking (using GLIDE) studies were used to reveal its interactions and binding poses with these targets at the molecular level. The results of molecular docking were in agreement with the binding mode of aminergic GPCR ligands previously described in literature, while MD simulations were mainly used to examine how D2AAK1 modulated the inactive conformation of the examined receptors. The obtained results were in concordance with in vitro studies, suggesting that this compound is an antagonist or partial agonist at these receptors based on the obtained specific conformations. Overall, this implies that such in silico methods may be used for assessment of the intrinsic efficacy of the compounds at GPCRs. Furthermore, the same team designed some new analogues of D2AAK1, whereas compound 3 (5) from Figure 3 with the most favourable multi-target profile was chosen for further molecular modelling, in vitro and in vivo studies (93). Finally, it can be concluded that VS plays a prominent role in the drug discovery process for the identification of new bioactive molecules and has already contributed to the compounds on the market (95).

Zięba and co-workers analysed dopamine $\mathrm{D}_{2}$ receptor antagonists employing the LBDD method (96). Taking into account that molecular alignment presents a crucial factor in CoMFA model building, they performed a 3D-QSAR analysis for structurally unrelated compounds using molecular docking-based alignment. The studied compounds were aligned by electrostatic interaction between the positively charged nitrogen of the ligand and the polar D3.32 residue, as it was described as essential for aminergic receptors, as well as by equivalent substituents of structurally different compounds (97). GLIDE programme from the Schrödinger software was used for the docking study, while the 3D-QSAR CoMFA model was built with SYBYL-X. In this context, the obtained results were used to discuss the structure-activity relationship of the studied ligands based on their interactions with the receptor.

In a recent investigation, Radan et al. integrated a number of CADD methods, including MD simulation, molecular docking, and 3D-QSAR modelling in order to analyse the 3D-structure of the pharmacophore and binding kinetics of structurally different 5-HT2A receptor antagonists (98). Based on chemical structures, dataset compounds were separated into three clusters representing dibenzodiazepine, 1,2-benzoisothiazole and sulfonylpyridine derivatives. Structure-based methods were 
used not only to examine how structurally different antagonists bind and modulate activity of this receptor, but also to generate their virtually bioactive conformations. Firstly, a complex of each cluster representative with $5-\mathrm{HT}_{2} \mathrm{~A}$ receptor was submitted to $50 \mathrm{~ns}$ long MD simulation to obtain their inactive, antagonist-bound conformations. The obtained conformations were further used for docking studies in order to generate virtually bioactive conformations of all studied ligands, as well as to investigate their binding modes in the active site of the receptor. MD simulation was performed with the NAMD software, while docking studies were performed with both AutoDock Vina and GOLD programs. Afterward, the predicted bioactive conformers were utilized to develop 3D-QSAR models by using the Pentacle program and therefore to gain further insights into the structural requirements that affect their antagonistic activity on 5-HT2A receptor (99). Overall, the results obtained through performed LBDD and SBDD studies as well as ADMET profiling may provide information that can be used for further optimization of compounds as well as for rational drug design. A summary of the aforementioned process is depicted in Figure 5.

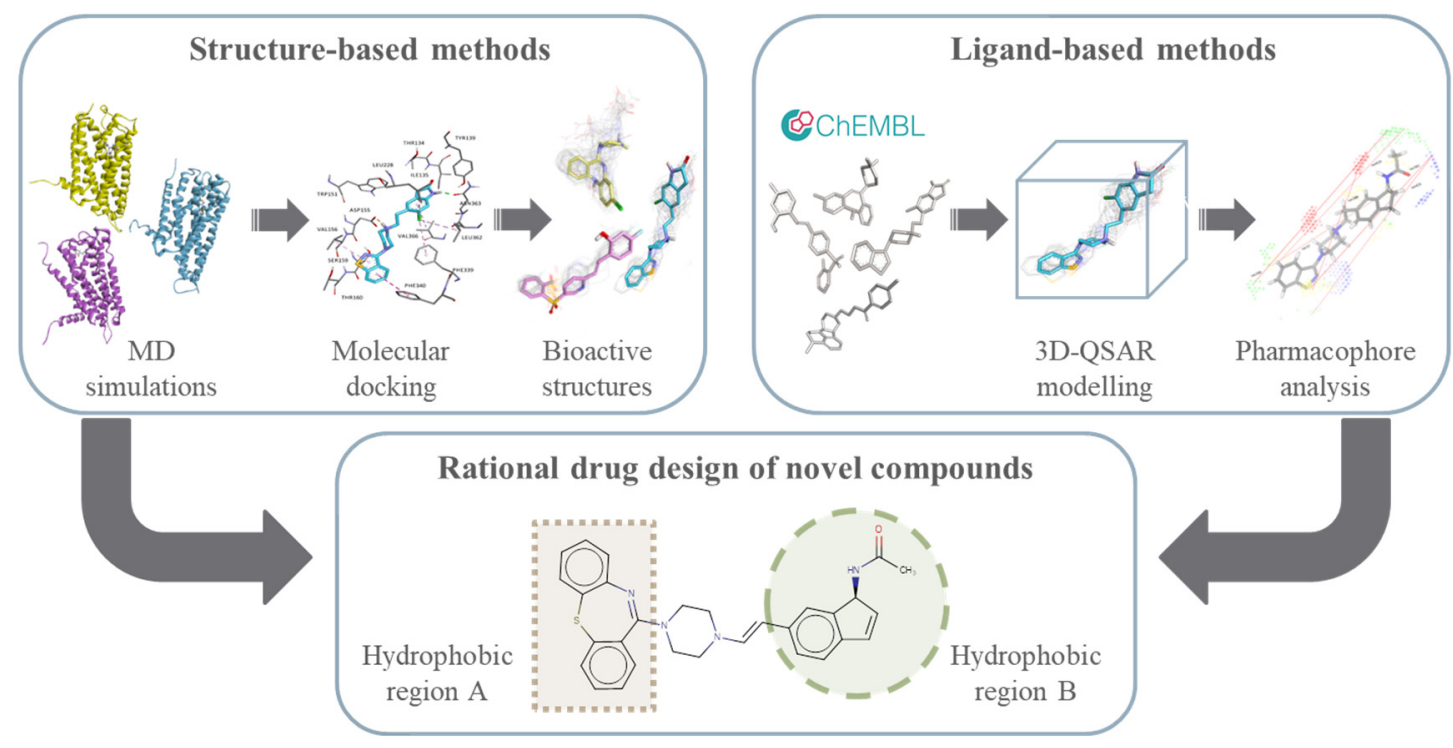

Figure 5. Overview of Radan et al. study (98)

Slika 5. Skicirani prikaz studije objavljene od strane Radan et al. (98)

In an effort to provide better efficiency and fewer adverse effects of drugs in treatment of complex neuropsychiatric disorders, many studies employed the multi-target approach in drug design and synthesis. It is currently a hot topic in GPCR-oriented research and some examples are described below.

Zaręba et al. reported new bulky analogues of arylpiperazine (LCAP- long chain arylpiperazines) as multi-functional antidepressants (100). The activities of new ligands were assessed both by in vitro testing as well as by using the molecular docking method. 
Among a number of synthesized compounds, five were classified as dual ligands for $\mathrm{D}_{2}$ and 5-HT1A receptors, and two of them, compounds 4 (5.3a) and 5 (5.4) from Figure 3, showed the most favourable properties. In recent studies, $5-\mathrm{HT}_{1 \mathrm{~A}}$ receptor was described as a promising target of novel antidepressants (101). Through the application of the molecular docking method they aimed to clarify SAR (structure-activity relationship) analysis and concluded that the studied compounds showed very similar binding mode for $5-\mathrm{HT}_{1 \mathrm{~A}}$ receptor, while different conformations were observed in the $\mathrm{D}_{2}$ receptor binding pocket. Since ligand 5 (5.4) showed the highest affinity for the $\mathrm{D}_{2}$ receptor, it was explained by the largest number of hydrophobic interactions in the binding site compared to others.

In order to search for potential multi-target antipsychotics, Zhu et al. designed new aryl-piperazine ligands based on FW01 (compound 6 from Figure 3), which is a potent agonist of the 5-HT $\mathrm{H}_{1 \mathrm{~A}}$ receptor discovered by dynamic pharmacophore-based VS in their previous study $(102,103)$. They employed molecular hybridization strategy with the aim of synthesizing new derivatives with dual $\mathrm{D}_{2}$ and 5-HT2A antagonistic activity. In this context, the $\mathrm{D}_{2}$ receptor binding pocket was divided into the orthosteric binding site (OBS), and a second binding site (SBS) and new compounds were designed so as to enhance binding interactions compared to the FW01 compound. The designed compounds were further analysed through an in vitro study, and compound 7 (9f) was selected as a potent dual $\mathrm{D}_{2}$ and 5- $\mathrm{HT}_{2} \mathrm{~A}$ receptors antagonist, with no activity on 5-HT1A receptor (Figure 3). A molecular docking study (using GOLD software) confirmed the obtained results and revealed strong interactions of compound 7 with D3.32, T3.37 and $\mathrm{T} 7.39$ in the $\mathrm{D}_{2}$ receptor binding site, and with $\mathrm{D} 3.32$, T3.37, S5.46 and L45.52 in the 5$\mathrm{HT}_{2 \mathrm{~A}}$ receptor binding site, whereas unfavourable interaction was determined within the $5-\mathrm{HT}_{1 \mathrm{~A}}$ receptor binding site. Overall, this compound makes a good candidate for further optimization and design of novel dual antagonists.

Another series of multi-target ligands was recently investigated by Shi et al. (104). They synthesized triazolopyridinone derivatives and evaluated their affinity for the 5$\mathrm{HT}_{2 \mathrm{~A}}, 5-\mathrm{HT}_{1 \mathrm{~A}}$ and $\mathrm{D}_{2}$ receptors through in vitro and molecular docking studies. The multi-receptor affinity profile of compound 8 (S1) from Figure 3 was especially promising and was selected for further preclinical investigation.

In December 2019, the Food and Drug Administration (FDA) approved lumateperone (Figure 3 ) as potent dual $5-\mathrm{HT}_{2} \mathrm{~A} / \mathrm{D}_{2}$ receptor antagonists, for the treatment of schizophrenia in adults (105). Also, this drug is under clinical trials for other neurological and neuropsychiatric disorders. An interesting compound, SEP-363856 (Figure 3), is currently undergoing clinical trials for the treatment of schizophrenia (106). It is a unique compound with a non- $\mathrm{D}_{2} / 5-\mathrm{HT}_{2 \mathrm{~A}}$ mechanism of action discovered with in vitro screening. Even though the mechanism of action is not yet completely revealed, data show that agonism at both TAAR1 and 5-HT1A receptors is essential to its efficacy (107). Trace amine-associated receptors (TAARs) are aminergic GPCRs located in the brain and periphery with an important role in human physiology and pathophysiology (108). Overall, the design of multi-target drugs in a rational way remains a great challenge, due 
to the necessity to balance the affinity to all desired targets and reducing affinity to offtargets. Nevertheless, it is currently the best option for the treatment of complex neuropsychiatric disorders.

\section{Successful application of CADD approaches in the discovery of dual COX-2 and 5-LOX inhibitors for treatment of inflammatory diseases}

Many inflammatory disorders are caused by the excessive production of arachidonic acid cascade mediators by cyclooxygenase and lipoxygenase pathways. Nonselective non-steroidal anti-inflammatory drugs (NSAIDs) block the activity of both cyclooxygenase- 1 and cyclooxygenase- 2 enzymes. They are used in the therapy of numerous inflammatory conditions, like temporary pain, osteoarthritis, rheumatoid arthritis (prolonged use). Traditional NSAIDs were associated with a lot of side effects (primarily gastrointestinal); thus, selective COX-2 inhibitors (coxibs) were introduced. Unfortunately, both traditional NSAIDs and coxibs are linked with increased cardiovascular risk. It is assumed that the inhibition of cyclooxygenase pathway could switch the metabolism to LOX pathway and cause an overproduction of inflammatory mediators. Therefore, dual inhibition of COX-2 and 5-LOX enzymes represents a reasonable approach used in the development of safer drugs with anti-inflammatory activity. The available crystal structures of enzyme-ligand complexes provide information about key interactions between the substrate and the active site of enzyme, which are important in computer-aided development of new drugs (Table II) (109-112). The design of dual COX-2 and 5-LOX inhibitors has been performed by the modification of the already known NSAIDs (introducing LOX pharmacophores) or by using computational techniques in order to obtain new scaffolds (113).

Table II Crystal structures of COX-2 and 5-LOX enzymes from PDB database

Tabela II Kristalne strukture COX-2 i 5-LOX enzima preuzete iz PDB baze podataka

\begin{tabular}{|c|c|c|c|c|c|}
\hline \multirow{4}{*}{$\begin{array}{c}\text { COX-2 } \\
\text { enzyme }\end{array}$} & PDB ID & Resolution & Ligand name & Function & Reference \\
\cline { 2 - 6 } & $5 \mathrm{IKV}$ & 2.51 & Flufenamic acid & Inhibitor & $(109)$ \\
\cline { 2 - 6 } & $6 \mathrm{COX}$ & 2.80 & SC-558 & Inhibitor & $(110)$ \\
\hline \multirow{2}{*}{$\begin{array}{c}\text { 5-LOX } \\
\text { enzyme }\end{array}$} & $3 \mathrm{CX} 2$ & 3.00 & SC-558 & Inhibitor & $(110)$ \\
\cline { 2 - 6 } & $3 \mathrm{~V} 99$ & 2.40 & $/$ & $/$ & $(111)$ \\
\hline
\end{tabular}

The most studied compounds with dual COX-2 and 5-LOX inhibitory activity are di-tert-butylphenol derivatives. It was demonstrated that 2,6-di-tert-butylphenol which contains a substituent in the $\mathrm{C} 4$ position is important scaffold for dual inhibition of COX2 and 5-LOX enzymes (Figure 6). It was assumed that the phenol moiety, which contains antioxidant properties, was important for anti-inflammatory activity. Considering radical scavenging activity, these compounds could potentially be useful in the therapy of radical-mediated disorders like cancer and allergic conditions. Some compounds were 
involved in clinical trials at some point in time (tebufelone, R-830, BF389, darbufelone (CI-1004) and S2474) (114-118). Many subsequent studies relied on this information. Some of di-tert-butylphenol derivatives that act as COX and 5-LOX dual inhibitors were developed according to performed structure-activity relationship (SAR) studies, such as darbufelone, S-2474, tebufelone and others (Figure 6) $(115,118)$.

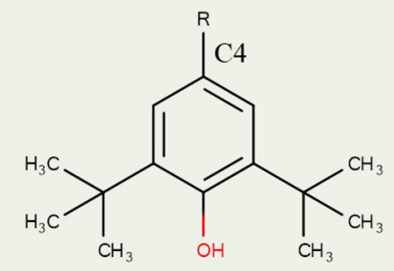

General structure

2,6-di-tert-butyl-1-hydroxy-benzene

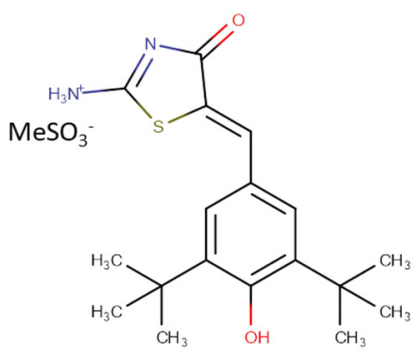

Darbufelone

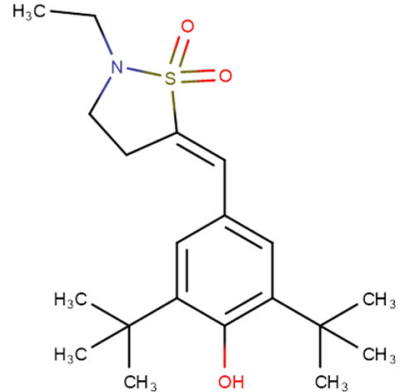

S-2474

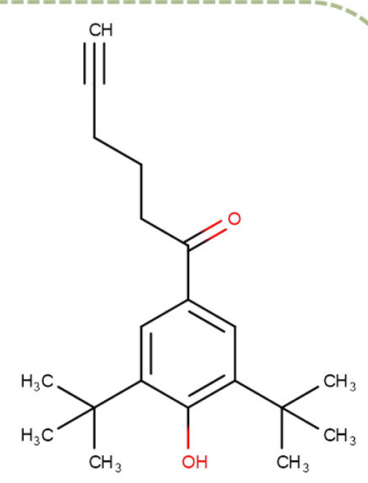

Tebufelone

Figure 6. General structure (2,6-di-tert-butyl-1-hydroxy-benzene substituted in the C4 position) and structures of dual COX-2/5-LOX inhibitors (darbufelone (116), S-2474 (117) and tebufelone (114))

Slika 6. Opšta struktura (2,6-di-terc-butil-1-hidroksi-benzen supstituisan u položaju C4) i strukture dualnih COX-2/5-LOX inhibitora (darbufelon (116), S-2474 (117) i tebufelon (114))

Ghatak et al. reported that newly designed di-tert-butyl phenol derivatives (di-tertbutyl phenylhydrazone based compounds: DTPSAL, DTPBHZ, DTPINH and DTPNHZ; Figure 7) showed a significant inhibition of COX-2 and 5-LOX enzymes and demonstrated cytotoxicity against human colorectal cancer (CRC) cell lines (119). Molecular docking studies were performed with the aim of obtaining information about interactions with protein residues within the active sites of COX-2 and 5-LOX enzymes and for the evaluation of the efficacy of synthesized dual inhibitors. For this purpose, AutoDock Vina software was used. As a result, compounds DTPBHZ and DTPSAL showed the best fit in the protein pocket of COX-2 enzyme with binding energies -10.1 
$\mathrm{Kcal} / \mathrm{mol}$ and $-9.7 \mathrm{Kcal} / \mathrm{mol}$, respectively. Compound DTPSAL exhibited binding energy of $-8.2 \mathrm{Kcal} / \mathrm{mol}$ when docked to 5-LOX enzyme (PDB ID: 3O8Y) and this value was lower than the binding energy of darbufelone (already known dual inhibitor, -7.73 $\mathrm{Kcal} / \mathrm{mol}$ ). It can be concluded that all novel di-tert-butyl phenol compounds have high binding affinities for COX and LOX active sites, which is in compliance with in vitro results.

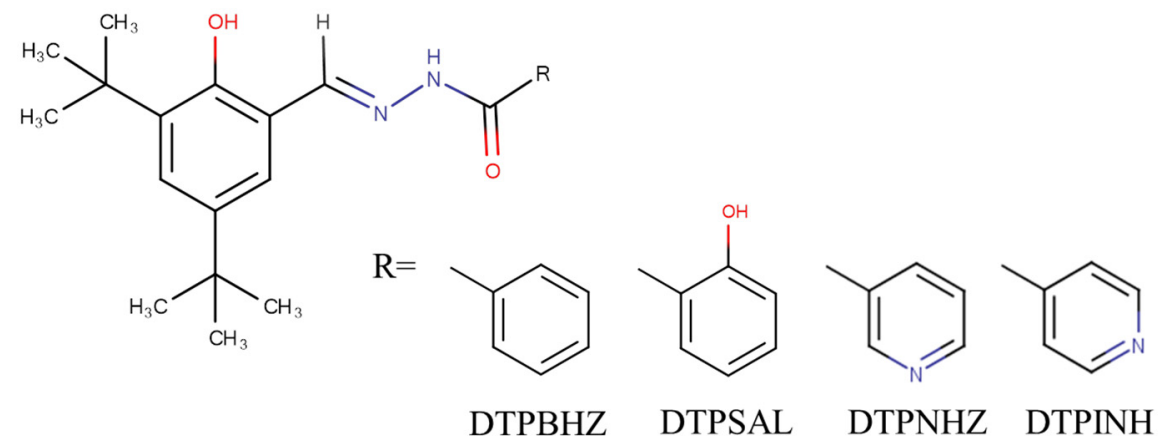

Figure 7. Structures of di-tert-butyl phenylhydrazone ligands: DTPBHZ, DTPSAL, DTPNHZ and DTPINH adopted from refrence 119

Slika 7. Strukture di-terc-butil fenilhidrazon liganada: DTPBHZ, DTPSAL, DTPNHZ and DTPINH preuzete iz reference 119

Lino et al. developed new dual COX and 5-LOX inhibitor LQFM-091 (di-tertbutylphenol compound) obtained from darbufelone and nimesulide (Figure 8) (120). A colorimetric screening assay and molecular docking study were performed with the aim of explaining the underlying mechanism of action. COX-1, COX-2 and 5-LOX crystal structures were obtained from the PDB database. Avogadro was used for structure drawing, Gaussian (MP2) for the calculation of partial charges and AutoDockTools4 for final structure preparation $(121,122)$. The molecular docking study was performed using DockThor and Vina (123). Both programs succeeded to pose LQFM-091 near or in the active sites of enzymes. A visual comparison between the best-ranked LQFM-091 poses and poses of darbufelone and nimesulide was carried out using PyMOL (The PyMOL Molecular Graphics System, version 1.8). LigPlot $^{+}$v1.4.5 was used for the estimation of interactions between the protein and ligand (124). Darbufelone, nimesulide and LQFM091 were similarly docked into the active sites of enzymes. In conclusion, the molecular docking study revealed that LQFM-091 interacted with important residues for the catalytic activity of all tested enzymes in a similar manner as darbufelon and nimesulide. In addition, in vitro studies showed that LQFM-091 is a dual COX and 5-LOX inhibitor, which confirmed the molecular docking results. 
<smiles>CC(C)(C)c1cc(/C=C2\SC(N)NC2=O)cc(C(C)(C)C)c1O</smiles>

\section{Molecularhybridization}

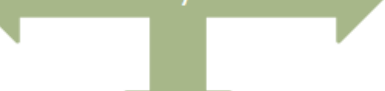

Darbufelone<smiles>C[SH](=O)(O)Nc1ccc([N+](=O)[O-])cc1Oc1ccccc1</smiles>

Nimesulide<smiles>CC(C)(C)c1cc(CNc2ccc([N+](=O)[O-])cc2)cc(C(C)(C)C)c1O</smiles>

LQFM 091

Figure 8. Design of di-tert-butylphenol compound LQFM 091 from darbufelone and nimesulide adopted from reference 120

Slika 8. Dizajn di-terc-butilfenol jedinjenja LQFM 091, iz darbufelona i nimesulida, preuzeto iz reference 120

Dihydrodimethylbenzofuran (DHDMBF) is metabolite of di-tert-butylphenol tebufelone which showed an anti-inflammatory activity comparable to tebufelone. It was demonstrated that 5-keto-substituted DHDMBFs have in vitro COX-2 and 5-LOX inhibitory activity and potent in vivo analgesic and anti-inflammatory activity when administered orally (125). The general structure of DHDMBF (compound 9) analogues is presented in Figure 9. 
<smiles>[2H]c1cc(Br)cc2c1OCC2([2H])[2H]</smiles>

9-(DHDMBF)<smiles>CC(C)(C)C1=CC(=NNC(=O)c2ccncc2)C=C(C(C)(C)C)C1=O</smiles>

12-(BQIH)<smiles>Cn1c(=O)ccc2cc(COc3cc(F)cc(C4(O)CCOCCO4)c3)ccc21</smiles>

15-(21)

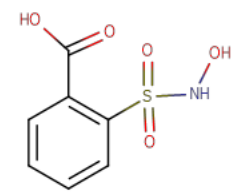

18-(11)<smiles>CC(C)(C)C1=CC(=NNC(=O)c2ccccc2)C=C(C(C)(C)C)C1=O</smiles>

10-(BQBH)<smiles></smiles>

13-(1-19)<smiles>COc1cc(/C=C2\SC(Nc3nccs3)=NC2=O)ccc1O</smiles>

16-(2)

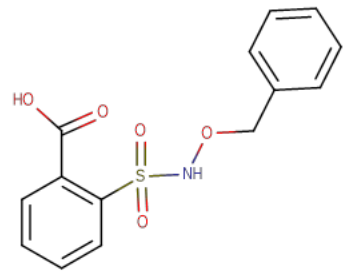

19-(12)<smiles>CC(C)(C)C1=CC(=NC(=O)c2ccccc2)C=C(C(C)(C)C)C1=O</smiles>

11-(BQNH)<smiles></smiles>

14-(20)

17-(5)<smiles>CCOC(=O)c1ccccc1N=C(C)CC</smiles>

20-(16)

Figure 9. Structures of novel dual COX-2 and 5-LOX inhibitors adopted from references $125(9), 125(10,11,12), 131(13,14,15), 137(16,17)$ and $140(18,19,20)$

Slika 9. Strukture novih dualnih COX-2 and 5-LOX inhibitora preuzete iz referenci $125(9), 125(10,11,12), 131(13,14,15), 137(16,17)$ and $140(18,19,20)$

Zheng et al. performed homology modelling and MD simulations of 5-LOX enzyme, as well as 3D-QSAR studies and molecular docking on DHDMBFs analogues 
(COX-2 and 5-LOX dual inhibitors) in order to reveal a common binding mode in COX2 and 5-LOX enzymes, explain conclusions from SAR studies and create highly predictive QSAR models which could be used in the development of new compounds that act as dual inhibitors (126). They created a homology model of the human 5-LOX enzyme by using the X-ray structure of the 15-LOX enzyme as a prototype. MODELLER was used for the creation of ten 5-LOX models. Further optimization of these models was performed via a conjugate gradient minimization scheme, followed by a restrained simulated annealing MD simulation (127). Based on the obtained results, a representative 5-LOX model was selected. COX-2 crystal structure was downloaded from PDB (PDB ID: 6COX). Further equilibration of the 3D model was performed using the AMBER 7.0 program (4-ns MD simulation). As a result, iron ligand residues, which are important for the 5-LOX activity, were precisely aligned. High reliability of the created final 5-LOX model was indicated by the high score. Twenty-seven DHDMBFs analogues from literature were docked into the active sites of both enzymes. The prediction of binding free energies of the docked compounds was performed by using the Auto Dock 3.0.3. programme, after structure optimization. The predicted binding free energies (both enzymes) for all compounds were in a good correlation with the experimental inhibitory activities (-logIC50). Twenty-one DHDMBF analogues were selected for CoMFA and CoMSIA studies, according to the binding conformations acquired from the performed molecular docking study. These studies were carried out with the aim of creating models which could be used for the design of new dual inhibitors. In conclusion, the performed modelling provided an explanation of binding modes of DHDMBF analogues within COX-2 and 5-LOX enzymes, while the 3D-QSAR study provided models that could be used in the development of novel potent dual inhibitors.

It was found that darbufelone acts as an inhibitor of growth of non-small cell lung cancer cell lines. Despite this discovery, di-tert-butyl phenols and their prodrugs di-tertbutyl benzoquinones remained incompletely investigated. Misra et al. synthesized three di-tert-butyl benzoquinone inhibitors attached to hydrazide side chain, named BQBH, BQNH and BQIH (compounds 10, 11 and 12, respectively in Figure 9) (128). These derivatives were docked into COX-2 and 5-LOX enzymes. They were also evaluated for inhibitory activities on both enzymes and cytotoxicity against colon cancer cell lines. The crystal structures for COX-2 and 5-LOX enzymes were downloaded from PDB site (PDB ID COX-2: 6COX; 5-LOX: 3O8Y). The AutoDock-Vina was used to dock BQBH, BQNH, BQIH and darbufelone in the active sites of targeted enzymes. In the case of docking to the COX-2 enzyme, calculated binding energies were in the range from -6.8 to $-7.2 \mathrm{Kcal} / \mathrm{mol}$ and the best result was obtained for BQNH. For the 5-LOX enzyme, calculated binding energies for BQNH, BQIH, darbufelone and $\mathbf{B Q B H}$ were in the range from -7.0 to $-8.4 \mathrm{Kcal} / \mathrm{mol}$, respectively. The molecular docking study indicated that all the tested compounds interact with amino acid residues within the active sites of both enzymes. Compound BQNH expressed the highest binding energy in both enzymes. In vitro tests confirmed that di-tert-butyl benzoquinones analogues are effective $\mathrm{COX}$ and 5-LOX inhibitors (128). 
Ruiz et al. tested the dual COX and 5-LOX inhibitory activity of 24 mono-, 2,6-ditert-butyl and unsubstituted phenols taken from the literature (115). Twenty compounds were di-ortho substituted phenols (tert-butyl groups in ortho positions), which is an essential scaffold for antioxidant activity, while various substituents were introduced in para position of the phenol. The remaining four compounds, with mono or unsubstituted ortho positions (tert-butyl or methyl groups), were also considered in order to test the effect of tert-butyl groups in ortho positions. The conformational variability of the compounds was investigated. A conformational study was carried out after molecular mechanics (MM) calculations (for building up initial geometries) and it was performed using semi-empirical AM1 method (incorporated in MOPAC 6.0 ESP program). Geometry optimization of minimum energy conformations (HF/6-31G(d) ab initio level) was performed using GAUSSIAN-94 program (129). The possible active conformations were selected using molecular superimposition between minimum energy conformations and the optimized conformations of active dual inhibitor tebufelone. According to the performed conformational analysis, molecular flexibility could be important for the modulation of COX and 5-LOX inhibitory activity. MEPMIN program was used for the drawing of molecular electrostatic potential maps (MEP) (130). GRID program was used for the representation of favorable interaction regions for each compound. For this purpose, various probes such as hydrophobic (DRY), water $(\mathrm{OH} 2)$, ferric and ferrous iron cation $\left(\mathrm{Fe}^{3+}\right.$ and $\left.\mathrm{Fe}^{2+}\right)$ were used. It can be concluded that di-tert-butyl phenol analogues can occupy four common minimum energy conformations that show a correct fit with the structure of tebufelone. The presence of electron-donating substituents (tert-butyl group in ortho positions of the phenol ring) favours phenoxyl radical formation and the hydrophobic interactions within the active sites of COX and LOX enzymes according to the performed QSAR studies. High EHOMO (energy of the highest-occupied molecular orbital) and low ferric cation interaction energies were calculated for the most active dual inhibitors, which indicates a probable Fe redox mechanism for LOX inhibition. The predictive ability of the suggested QSAR equations was tested with selective dual COX and 5-LOX inhibitors.

Pommery et al. synthesized and in vitro tested diarylpyrazole derivatives for COX2 and 5-LOX inhibitory activity (131). They also performed molecular modelling approach and proposed a set of SAR data important for further investigations of this group of compounds.

Revathi et al. perfomed a QSAR study on 1,5-diarylpyrazoles in order to obtain information about the structural features important for COX-2 and 5-LOX inhibitory activity (132). The inhibitory activities of 1,5-diarylpyrazole derivatives (compounds $\mathbf{1 3}$ and 14, Figure 9) on COX-1, COX-2 and 5-LOX enzymes were taken from literature (131). CS ChemOffice version 8.0 (133) and Dragon program (134) were used for modelling the study (structures drawing and computation of molecular descriptors), while VALSTAT (135) was used for regression analysis. At first, the structures were optimized using molecular mechanics (MM2), then re-optimized via Austin model-1 (AM1) method 
using MOPAC and the geometry optimization of the lowest energy structure was performed using the EF routine. Molecular descriptors were calculated in the Dragon program. The obtained data were further transferred to VALSTAT to find a correlation between independent (molecular descriptors) and dependent variables (pIC50 values) using the sequential multiple linear regression analysis method. As a result of the performed QSAR study, important information about structural insights was obtained. Hy (hydrophilic factor) and Mor17v (3D molecular representation of structure based on electron diffraction code) are the descriptors essential for the development of more selective COX-2 and 5-LOX dual inhibitors.

Thiazole and thiazolidinone scaffolds can be found in many of pharmacologically active compounds. Liaras et al. explored the effects of thiazole and thiazolidinone derivatives on COX and LOX enzymes (136). According to the performed study, these compounds could be an encouraging initial point for the future development of potent and safer COX and LOX inhibitors.

In a study performed by Geronikaki et al. (137), CADD approach (PASS software (138)) was used in order to predict the biological activity of 573 in silico designed compounds (thiazole/benzothiazoles and benzoisothiazoles) and the obtained results were further analyzed by the Pharma Expert software (139). Anti-inflammatory activity was predicted for thirty-one compounds, while twenty-two were nonspecific COX and specific 5-LOX inhibitors. These twenty-two compounds were 2-(thiazole-2-ylamino)-5phenylidene-4-thiazolidinone derivatives. Nine of them were selected for biological assays and eight derivatives expressed anti-inflammatory activity in in vitro experiments (Figure 7). According to the results of the performed in vitro experiments, compounds $\mathbf{1 6}$ (2) and 17 (5) from Figure 9 showed the highest anti-inflammatory activity. The most active compounds were docked to COX-2 and 15-LOX enzymes with the aim of obtaining information about binding modes. GOLD 3.0.1 software was used for the molecular docking study. Goldscore (GS), ChemScore (CS), PLP 1 and 2, LigScore 1 and 2 and PMF scoring functions were used in order to find the best pose. The docking results provided a good explanation about the inhibitory activity of the most active compounds.

Kaur et al. designed and synthesized analogues of aspirin in order to evaluate dual COX-2 and 5-LOX inhibitory activity (140). The design was based on the assumption that the replacement of acetoxy moiety of aspirin with a sulfohydroxamic moiety ( $\mathrm{SO}_{2} \mathrm{NHOR}: \mathrm{R}=\mathrm{H}, \mathrm{CH}_{2} \mathrm{Ph}, \mathrm{Me}$ ) would lead to the development of new compounds with a more potent activity. It was presumed that sulfohydroxamic moiety acts as a COX-2 pharmacophore (similar to celecoxib, a selective COX-2 inhibitor), 5-LOX pharmacophore (similar to 5-LOX inhibitors - iron chelators) and nitric oxid (NO) donor, inducing vascular smooth-muscle relaxation. According to in vitro studies, compounds 18 (11), 19 (12) and 20 (16) act as selective and highly potent COX-2 inhibitors, while compounds 18 (11) and 20 (16) also expressed high 5-LOX inhibitory activity (Figure 9). Compounds 18 (11) and 20 (16) with unsubstituted $\mathrm{SO}_{2} \mathrm{NHOH}$ moiety appeared to be good NO donors. In order to explore the interactions into active sites of COX-1, COX-2 and 5-LOX enzymes (PDB ID: COX-1: 1EQG, COX-2: 6COX, 5-LOX: 3O8Y), 
molecular docking studies were performed. The ArgusLab 4.0.1 software was used for structure building, structure geometry optimization (using semiempirical quantum mechanical method PM3) and docking (141). Active sites of selected monomeric structures of enzymes were defined around the ligand. Docking was based on a grid-based algorithm and a simulation was performed between flexible ligand parts and the enzyme. The shape scoring function determined ligand orientation, while final positions were ranked according to the lowest energy values. Discovery studio 3.0. was used for visual inspection of interactions within the active region of the 5-LOX enzyme (142). The results of the performed molecular docking studies were in accordance with the experimental biological data.

Just a few dual COX-2 and 5-LOX inhibitors were involved in clinical trials as antiinflammatory agents; among them, only licofelone entered phase III, while tenidap was withdrawn due to hepatotoxicity (143). Although these compounds have not been registered yet, they might represent a worthy therapeutic alternative to classical NSAIDs in the treatment of various inflammatory conditions and a wide variety of diseases.

\section{Conclusion}

Nowadays, CADD approaches form an integral part of the drug discovery process. In general, they are divided into ligand-based and structure-based drug design approaches, while their integration may provide more extensive information in the design of novel therapeutics. LBVS methods are usually combined with molecular docking to identify potential lead molecules from huge compound libraries as promising starting points for further ligand optimization studies. MD simulations offer valuable insights into protein structure and dynamics, therefore providing a variety of information for further LBDD and SBDD methods. Since the protein undergoes conformational changes upon binding different classes of ligands, utilizing MD simulation may be crucial in defining the appropriate biding site for a molecular docking study. Furthermore, the integration of 3D-QSAR and molecular docking methods in rational drug design presents a beneficial strategy for the development of highly predictive models. 3D-QSAR models are generated on the basis of virtually predicted bioactive conformations, enabling more trustworthy results of the structure-activity relationship analysis. Finally, the results obtained through applications of various CADD methods may be used for structural modification and design of novel compounds, as well as for guiding experimental studies. Both computational and experimental methods are complementary approaches which have important roles in drug discovery. The rationalization of the drug design process combining these methods will result in deeper and more innovative research of novel potential therapeutics. This review provided a brief introduction to computational approaches and their uses to identify potential drug candidates that might be used as future therapeutics for neuropsychiatric and inflammatory diseases. 


\section{Acknowledgements}

This research was funded by the Ministry of Education, Science and Technological Development, Republic of Serbia, through Grant Agreement with the University of Belgrade - Faculty of Pharmacy No: 451-03-9/2021-14/200161

\section{References:}

1. Mohs RC, Greig NH. Drug discovery and development: Role of basic biological research. Alzheimers Dement (N Y). 2017;3(4):651-657.

2. Hughes JP, Rees S, Kalindjian SB, Philpott KL. Principles of early drug discovery. Br J Pharmacol. 2011;162(6):1239-49.

3. Kiriiri GK, Njogu PM, Mwangi AN. Exploring different approaches to improve the success of drug discovery and development projects: a review. Futur J Pharm Sci. 2020;6:27.

4. Sinha S, Vohora D. Chapter 2 - Drug Discovery and Development: An Overview. In: Vohora D, Singh G, editors. Pharmaceutical Medicine and Translational Clinical Research: Drug Discovery and Development. Elsevier; 2018; 19-32 p.

5. Kapetanovic IM. Computer-aided drug discovery and development (CADDD): in silico-chemicobiological approach. Chem Biol Interact. 2008;171(2):165-176.

6. Lin X, Li X, Lin X. A Review on Applications of Computational Methods in Drug Screening and Design. Molecules. 2020;25(6),1375.

7. Bisht N, Singh BK: Role of computer aided drug design in drug development and drug discovery. Int J Pharm Sci Res. 2018;9(4):1405-15.

8. Surabhi S, Singh BK, Computer Aided Drug Design: An Overview. JDDT. 2018;8(5):504-509.

9. Sliwoski G, Kothiwale S, Meiler J, Lowe EW. Computational methods in drug discovery. Pharmacol. Rev. 2014;66(1):334-395.

10. Baig MH, Ahmad K, Rabbani G, Danishuddin M, Choi I. Computer Aided Drug Design and its Application to the Development of Potential Drugs for Neurodegenerative Disorders. Curr Neuropharmacol. 2018;16(6):740-8.

11. Nikolic K, Mavridis L, Djikic T, Vucicevic J, Agbaba D, Yelekci K, et al. Drug Design for CNS Diseases: Polypharmacological Profiling of Compounds Using Cheminformatic, 3D-QSAR and Virtual Screening Methodologies. Front Neurosci. 2016;10:265.

12. Baldi A. Computational approaches for drug design and discovery: An overview. Sys Rev Pharm. 2010;1(1):99.

13. Kore PP, Mutha MM, Antre RV, Oswal RJ, Kshirsagar SS. Computer-Aided Drug Design: An Innovative Tool for Modeling. OJMC. 2012;02(04):139-48.

14. Yu W, MacKerell AD Jr. Computer-Aided Drug Design Methods. Methods Mol Biol. 2017;1520:85-106.

15. Leelananda SP, Lindert S. Computational methods in drug discovery. Beilstein J. Org. Chem. 2016;12:2694-2718. 
16. Ferreira LG, Dos Santos RN, Oliva G, Andricopulo AD. Molecular Docking and Structure-Based Drug Design Strategies. Molecules. 2015;20(7):13384-13421.

17. Berman, H.M. The protein data bank. Nucleic Acids Res. 2000;28:235-42.

18. Batool M, Ahmad B, Choi S. A Structure-Based Drug Discovery Paradigm. Int. J. Mol. Sci. 2019;20(11):2783.

19. Vyas VK, Ukawala RD, Ghate M, Chintha C. Homology modeling a fast tool for drug discovery: current perspectives. Indian J Pharm Sci. 2012;74(1):1-17.

20. Sali A, Blundell TL. Comparative protein modelling by satisfaction of spatial restraints. J Mol Biol. 1993;234(3):779-815.

21. Biasini M, Bienert S, Waterhouse A, Arnold K, Studer G, Schmidt T, Kiefer F, Gallo Cassarino T, Bertoni M, Bordoli L, Schwede T. SWISS-MODEL: modelling protein tertiary and quaternary structure using evolutionary information. Nucleic Acids Res. 2014;42(Web Server issue):W252-8.

22. Kalyaanamoorthy S, Chen Y-PP. Structure-based drug design to augment hit discovery. Drug Discov. Today. 2011;16(17-18):831-9.

23. Salo-Ahen OMH, Alanko I, Bhadane R, Bonvin AMJJ, Honorato RV, Hossain S, et al. Molecular Dynamics Simulations in Drug Discovery and Pharmaceutical Development. Processes. 2021;9(1):71.

24. Durrant JD, McCammon JA. Molecular dynamics simulations and drug discovery. BMC Biology. 2011;9(1):71.

25. Hollingsworth SA, Dror RO. Molecular Dynamics Simulation for All. Neuron. 2018;19;99(6):1129-1143.

26. Michael P. Allen. Introduction to molecular dynamics simulation. Computational soft matter: from synthetic polymers to proteins. 2004;23:1-27.

27. Hospital A, Goñi JR, Orozco M, Gelpí JL. Molecular dynamics simulations: advances and applications. Adv Appl Bioinform Chem. 2015;8:37-47.

28. Mura C, McAnany CE. An introduction to biomolecular simulations and docking. Mol Simul. 2014;40(10-11):732-64.

29. Anandakrishnan R, Drozdetski A, Walker RC, Onufriev AV. Speed of conformational change: comparing explicit and implicit solvent molecular dynamics simulations. Biophys J. 2015;108(5):1153-64.

30. Case DA, Cheatham TE 3rd, Darden T, Gohlke H, Luo R, Merz KM Jr, et al. The AMBER biomolecular simulation programs. J Comput Chem 2005;26:1668-88.

31. Brooks BR, Bruccoleri RE, Olafson BD, States DJ, Swaminathan S, Karplus M. CHARMM - a program for macromolecular energy, minimization, and dynamics calculations. J Comput Chem. 1983;4:187-217.

32. Christen M, Hünenberger PH, Bakowies D, Baron R, Bürgi R, Geerke DP, et al. The GROMOS software for biomolecular simulation: GROMOS05. J Comput Chem. 2005;26:1719-51.

33. Phillips JC, Braun R, Wang W, Gumbart J, Tajkhorshid E, Villa E, et al. Scalable molecular dynamics with NAMD. J Comput Chem. 2005;26:1781-1802.

34. Forli S, Huey R, Pique ME, Sanner MF, Goodsell DS, Olson AJ. Computational protein-ligand docking and virtual drug screening with the AutoDock suite. Nat Protoc. 2016;11(5):905-19. 
35. Meza Menchaca T, Juárez-Portilla C, C. Zepeda R. Past, Present, and Future of Molecular Docking. In: Gaitonde V, Karmakar P, Trivedi A, editors. Drug Discovery and Development - New Advances. IntechOpen; 2020.

36. Morris GM, Lim-Wilby M. Molecular docking. Methods Mol Biol. 2008;443:365-82.

37. Salmaso V, Moro S. Bridging Molecular Docking to Molecular Dynamics in Exploring LigandProtein Recognition Process: An Overview. Front Pharmacol. 2018;9:923.

38. Sethi A, Joshi K, Sasikala K, Alvala M. Molecular Docking in Modern Drug Discovery: Principles and Recent Applications. In: Gaitonde V, Karmakar P, Trivedi A, editors. Drug Discovery and Development - New Advances. IntechOpen; 2020.

39. Fan J, Fu A, Zhang L. Progress in molecular docking. Quant. Biol. 2019;7(2):83-9.

40. Meng XY, Zhang HX, Mezei M, Cui M. Molecular docking: a powerful approach for structure-based drug discovery. Curr Comput Aided Drug Des. 2011;7(2):146-57.

41. Morris GM, Huey R, Lindstrom W, Sanner MF, Belew RK,Goodsell DS, et al. AutoDock4 and AutoDockTools4: automateddocking with selective receptor flexibility. J Comput Chem. 2009;30:2785-91

42. Trott $\mathrm{O}$, Olson AJ. AutoDock Vina: improving the speed and accuracy of docking with a new scoring function, efficient optimization, and multithreading. J Comput Chem. 2010;31(2):455-61.

43. Verdonk ML, Cole JC, Hartshorn MJ, Murray CW, Taylor RD. Improved protein-ligand docking using GOLD. Proteins. 2003;52:609-23

44. Halgren TA, Murphy RB, Friesner RA, Beard HS, Frye LL, Pollard WT, et al. Glide: a new approach for rapid, accurate docking and scoring.2. Enrichment factors in database screening. J Med Chem. 2004:47:1750-59

45. Boittier ED, Tang YY, Buckley ME, Schuurs ZP, Richard DJ, Gandhi NS. Assessing Molecular Docking Tools to Guide Targeted Drug Discovery of CD38 Inhibitors. IJMS. 2020;21(15):5183.

46. Pagadala NS, Syed K, Tuszynski J. Software for molecular docking: a review. Biophys Rev. 2017;9(2):91-102.

47. Shoichet BK. Virtual screening of chemical libraries. Nature. 2004;432(7019): 862-5.

48. Banegas-Luna AJ, Cerón-Carrasco JP, Pérez-Sánchez H. A review of ligand-based virtual screening web tools and screening algorithms in large molecular databases in the age of big data. Future Med Chem. 2018;10(22):2641-2658.

49. Singh N, Chaput L, Villoutreix BO. Virtual screening web servers: designing chemical probes and drug candidates in the cyberspace. Brief Bioinform. 2021; 22(2):1790-1818.

50. Lyne PD. Structure-based virtual screening: an overview. Drug Discov Today. 2002; 7(20):1047-55.

51. Maia EHB, Assis LC, de Oliveira TA, da Silva AM, Taranto AG. Structure-Based Virtual Screening: From Classical to Artificial Intelligence. Front Chem. 2020;28;8:343.

52. Verma J, Khedkar VM, Coutinho EC. 3D-QSAR in drug design--a review. Curr Top Med Chem. 2010;10(1):95-115.

53. Cherkasov A, Muratov EN, Fourches D, Varnek A, Baskin II, Cronin M, et al. QSAR modeling: where have you been? Where are you going to? J Med Chem. 2014;57(12):4977-5010.

54. K. Roy, S. Kar, R. N. Das. A primer on QSAR/QSPR modeling, Springer, Cham. 2015, (pp. 37-59)

55. Aguayo-Ortiz R, Fernández-de Gortari E. Overview of computer-aided drug design for epigenetic targets. In MedinaFranco JL, editors. Epi-Informatics. 2016; p. 21-52. 
56. Dobričić V, Jaćević V, Vučićević J, Nikolic K, Vladimirov S, Čudina O. Evaluation of Biological Activity and Computer-Aided Design of New Soft Glucocorticoids. Arch Pharm (Weinheim). 2017;350(5).

57. Golbraikh A, Tropsha A. Beware of q2! J Mol Graph Model. 2002;20(4):269-76

58. van de Waterbeemd H, Gifford E. ADMET in silico modelling: towards prediction paradise? Nat Rev Drug Discov. 2003;2(3):192-204.

59. Krüger A, Maltarollo VG, Wrenger C, Kronenberger T. ADME Profiling in Drug Discovery and a New Path Paved on Silica. In: Gaitonde V, Karmakar P, Trivedi A, editors. Drug Discovery and Development - New Advances. IntechOpen; 2020.

60. Vucicevic J, Nikolic K, Dobričić V, Agbaba D. Prediction of blood-brain barrier permeation of $\alpha-$ adrenergic and imidazoline receptor ligands using PAMPA technique and quantitative-structure permeability relationship analysis. Eur J Pharm Sci. 2015 Feb 20;68:94-105.

61. Daina A, Michielin O, Zoete V. SwissADME: a free web tool to evaluate pharmacokinetics, druglikeness and medicinal chemistry friendliness of small molecules. Sci Rep. 2017 Mar 3;7:42717.

62. ADMET Predictor v 9.5, n.d. Simulations plus inc., lancaster, CA, USA https://www.simulationsplus

63. QikProp, Schrödinger, LLC, NY, 2019, https://www.schrodinger.com/

64. Michino M, Beuming T, Donthamsetti P, Newman AH, Javitch JA, Shi L. What Can Crystal Structures of Aminergic Receptors Tell Us about Designing Subtype-Selective Ligands? Pharmacol Rev. 2015;67(1):198-213.

65. Choudhury A, Sahu T, Ramanujam PL, Kumar Banerjee A, Chakraborty I, Kumar RA, et al. Neurochemicals, Behaviours and Psychiatric Perspectives of Neurological Diseases. Neuropsychiatry. 2018;8(1):395-424.

66. Vangveravong S, McElveen E, Taylor M, Xu J, Tu Z, Luedtke RR, et al. Synthesis and characterization of selective dopamine D2 receptor antagonists. Bioorg Med Chem. 2006;14(3):815-25.

67. Kapur S, Mamo D. Half a century of antipsychotics and still a central role for dopamine D2 receptors. Prog Neuropsychopharmacol Biol Psychiatry. 2003;27(7):1081-90.

68. Raote I, Bhattacharya A, Panicker MM. Serotonin 2A (5-HT2A) Receptor Function: LigandDependent Mechanisms and Pathways. In: Chattopadhyay A, editor. Serotonin Receptors in Neurobiology. Boca Raton (FL): CRC Press/Taylor \& Francis; 2007. Chapter 6.

69. Grinchii D, Dremencov E. Mechanism of Action of Atypical Antipsychotic Drugs in Mood Disorders. Int J Mol Sci. 2020;21(24):9532.

70. Worrel JA, Marken PA, Beckman SE, Ruehter VL: Atypical antipsychotic agents: a critical review. Am J Health Syst Pharm. 2000;57:238-55.

71. Butini S, Nikolic K, Kassel S, Brückmann H, Filipic S, Agbaba D, et al. Polypharmacology of dopamine receptor ligands. Prog Neurobiol. 2016;142:68-103.

72. Munk C, Isberg V, Mordalski S, Harpsøe K, Rataj K, Hauser AS, et al. GPCRdb: the G proteincoupled receptor database - an introduction. Br J Pharmacol. 2016;173(14):2195-207.

73. Vass M, Podlewska S, De Esch IJP, Bojarski AJ, Leurs R, Kooistra AJ, et al. Aminergic GPCRligand interactions: A chemical and structural map of receptor mutation data. J Med Chem. 2019;25;62(8):3784-3839. 
74. Oluić J, Nikolic K, Vucicevic J, Gagic Z, Filipic S, Agbaba D. 3D-QSAR, Virtual Screening, Docking and Design of Dual PI3K/mTOR Inhibitors with Enhanced Antiproliferative Activity. Comb Chem High Throughput Screen. 2017;20(4):292-303.

75. Gagic Z, Ruzic D, Djokovic N, Djikic T, Nikolic K. In silico Methods for Design of Kinase Inhibitors as Anticancer Drugs. Front Chem. 2020;7:873.

76. Ísberg V, Balle T, Sander, T, Jørgensen FS, Gloriam DE. G Protein- and Agonist-Bound Serotonin 5-HT2A Receptor Model Activated by Steered Molecular Dynamics Simulations. J Chem Inf Model. 2011;51:315-25.

77. Platania CB, Salomone S, Leggio GM, Drago F, Bucolo C. Homology modeling of dopamine D2 and D3 receptors: molecular dynamics refinement and docking evaluation. PLoS One. 2012;7(9):e44316.

78. Kim K, Che T, Panova O, DiBerto JF, Lyu J, Krumm BE, et al. Structure of a Hallucinogen-Activated Gq-Coupled 5-HT2A Serotonin Receptor. Cell. 2020;182(6):1574-1588.e19.

79. Kimura KT, Asada H, Inoue A, Kadji FMN, Im D, Mori C, et al. Structures of the 5-HT2A receptor in complex with the antipsychotics risperidone and zotepine. Nat Struct Mol Biol. 2019;26(2):121-8.

80. Zhuang Y, Xu P, Mao C, Wang L, Krumm B, Zhou XE, et al. Structural insights into the human D1 and D2 dopamine receptor signaling complexes. Cell. 2021;184(4):931-942.e18.

81. Im D, Inoue A, Fujiwara T, Nakane T, Yamanaka Y, Uemura T, et al. Structure of the dopamine D2 receptor in complex with the antipsychotic drug spiperone. Nat Commun. 2020;11(1):6442.

82. Yin J, Chen KM, Clark MJ, Hijazi M, Kumari P, Bai XC, et al. Structure of a D2 dopamine receptorG-protein complex in a lipid membrane. Nature. 2020;584(7819):125-9.

83. Fan L, Tan L, Chen Z, Qi J, Nie F, Luo Z, et al. Haloperidol bound D2 dopamine receptor structure inspired the discovery of subtype selective ligands. Nat Commun. 2020;11(1):1074.

84. Wang S, Che T, Levit A, Shoichet BK, Wacker D, Roth BL. Structure of the D2 dopamine receptor bound to the atypical antipsychotic drug risperidone. Nature. 2018;555(7695):269-73.

85. Lin F, Li F, Wang C, Wang J, Yang Y, Yang L, et al. Mechanism Exploration of Arylpiperazine Derivatives Targeting the 5-HT2A Receptor by In Silico Methods. Molecules. 2017;22(7):1064.

86. Zhang C, Li Q, Meng L, Ren Y. Design of novel dopamine D2 and serotonin 5-HT2A receptors dual antagonists toward schizophrenia: An integrated study with QSAR, molecular docking, virtual screening and molecular dynamics simulations. J Biomol Struct Dyn. 2020;38(3):860-85.

87. SYBYL-X. (Tripos International: 1699 South Hanley Road, St. Louis, MO 63144-2319, USA).

88. Irwin JJ, Sterling T, Mysinger MM, Bolstad ES, Coleman RG. ZINC: a free tool to discover chemistry for biology. J Chem Inf Model. 2012;52(7):1757-68.

89. Kumar R, Jade D, Gupta D. A novel identification approach for discovery of 5-HydroxyTriptamine 2A antagonists: combination of $2 \mathrm{D} / 3 \mathrm{D}$ similarity screening, molecular docking and molecular dynamics. J Biomol Struct Dyn. 2019 Mar;37(4):931-43.

90. Kaczor AA, Silva AG, Loza MI, Kolb P, Castro M, Poso A. Structure-Based Virtual Screening for Dopamine D2 Receptor Ligands as Potential Antipsychotics. ChemMedChem. 2016; 11, 718-29.

91. Small-Molecule Drug Discovery Suite 2015-4: Glide, version 6.9, Schrçdinger, LLC, New York, NY (USA), 2015; http://www.schrodinger.com/smdd/ 
92. Kaczor AA, Targowska-Duda KM, Budzyńska B, Biała G, Silva AG, Castro M. In vitro, molecular modeling and behavioral studies of 3-\{[4-(5-methoxy-1H-indol-3-yl)-1,2,3,6-tetrahydropyridin-1yl]methyl -1,2-dihydroquinolin-2-one (D2AAK1) as a potential antipsychotic. Neurochem Int. 2016;96:84-99.

93. Kondej M, Wróbel TM, Silva AG, Stępnicki P, Koszła O, Kędzierska E, et al. Synthesis, pharmacological and structural studies of 5-substituted-3-(1-arylmethyl-1,2,3,6-tetrahydropyridin-4yl)-1H-indoles as multi-target ligands of aminergic GPCRs. Eur J Med Chem. 2019;180:673-89.

94. Koszła O, Sołek P, Woźniak S, Kędzierska E, Wróbel TM, Kondej M, et al. The Antipsychotic D2AAK1 as a Memory Enhancer for Treatment of Mental and Neurodegenerative Diseases. Int J Mol Sci. 2020;21(22):8849.

95. Maia EHB, Assis LC, de Oliveira TA, da Silva AM, Taranto AG. Structure-Based Virtual Screening: From Classical to Artificial Intelligence. Front Chem. 2020;8:343.

96. Zięba A, Żuk J, Bartuzi D, Matosiuk D, Poso A, Kaczor AA. The Universal 3D QSAR Model for Dopamine D2 Receptor Antagonists. Int J Mol Sci. 2019;20(18):4555.

97. Kanagarajadurai K, Malini M, Bhattacharya A, Panicker MM, Sowdhamini R. Molecular modeling and docking studies of human 5-hydroxytryptamine 2A (5-HT2A) receptor for the identification of hotspots for ligand binding. Mol Biosyst. 2009 Dec;5(12):1877-88.

98. Radan M, Ruzic D, Antonijevic M, Djikic T, Nikolic K. In silico identification of novel 5-HT2A antagonists supported with ligand- and target-based drug design methodologies. J Biomol Struct Dyn. 2021;39(5):1819-37.

99. Pastor M, McLay I, Pickett S, Clementi S. Grid-Independent descriptors (GRIND): a novel class of alignment-independent three-dimensional molecular descriptors. Med Chem. 2000;43(17):3233-3243.

100. Zaręba P, Jaśkowska J, Śliwa P, Satała G. New dual ligands for the D2 and 5-HT1A receptors from the group of 1,8-naphthyl derivatives of LCAP. Bioorg Med Chem Lett. 2019;29(16):2236-2242.

101. Le François B, Zhang L, Mahajan GJ, Stockmeier CA, Friedman E, Albert PR. A Novel Alternative Splicing Mechanism That Enhances Human 5-HT1A Receptor RNA Stability Is Altered in Major Depression. J Neurosci. 2018;38(38):8200-8210.

102. Zhu C, Li X, Zhao B, Peng W, Li W, Fu W. Discovery of aryl-piperidine derivatives as potential antipsychotic agents using molecular hybridization strategy. Eur J Med Chem. 2020;193:112214.

103. Xu L, Zhou S, Yu K, Gao B, Jiang H, Zhen X, et al. Molecular modeling of the 3D structure of 5HT(1A)R: discovery of novel 5-HT(1A)R agonists via dynamic pharmacophore-based virtual screening. J Chem Inf Model. 2013;53(12):3202-11.

104. Shi W, Wang Y, Wu C, Yang F, Zheng W, Wu S, et al. Synthesis and biological investigation of triazolopyridinone derivatives as potential multireceptor atypical antipsychotics. Bioorg Med Chem Lett. 2020;30(8):127027.

105. Greenwood J, Acharya RB, Marcellus V, Rey JA. Lumateperone: A Novel Antipsychotic for Schizophrenia. Ann Pharmacother. 2021;55(1):98-104.

106. Koblan KS, Kent J, Hopkins SC, Krystal JH, Cheng H, Goldman R, et al. A Non-D2-ReceptorBinding Drug for the Treatment of Schizophrenia. N Engl J Med. 2020;382(16):1497-1506.

107. Dedic N, Jones PG, Hopkins SC, Lew R, Shao L, Campbell JE, et al. SEP-363856, a Novel Psychotropic Agent with a Unique, Non-D2 Receptor Mechanism of Action. J Pharmacol Exp Ther. 2019;371(1):1-14. 
108. Dodd S, F Carvalho A, Puri BK, Maes M, Bortolasci CC, Morris G, et al. Trace Amine-Associated Receptor 1 (TAAR1): A new drug target for psychiatry? Neurosci Biobehav Rev. 2021;120:537-541.

109. Orlando BJ, Malkowski MG. Substrate-selective Inhibition of Cyclooxygeanse-2 by Fenamic Acid Derivatives Is Dependent on Peroxide Tone. J Biol Chem. 2016;291(29):15069-81.

110. Kurumbail RG, Stevens AM, Gierse JK, McDonald JJ, Stegeman RA, Pak JY, Gildehaus D, Miyashiro JM, Penning TD, Seibert K, Isakson PC, Stallings WC. Structural basis for selective inhibition of cyclooxygenase-2 by anti-inflammatory agents. Nature. 1996;384(6610):644-8.

111. Gilbert NC, Bartlett SG, Waight MT, Neau DB, Boeglin WE, Brash AR, et al. The structure of human 5-lipoxygenase. Science. 2011;331(6014):217-9.

112. Gilbert NC, Rui Z, Neau DB, Waight MT, Bartlett SG, Boeglin WE, et al. Conversion of human 5lipoxygenase to a 15-lipoxygenase by a point mutation to mimic phosphorylation at Serine-663. FASEB J. 2012;26(8):3222-9.

113. P JJ, Manju SL, Ethiraj KR, Elias G. Safer anti-inflammatory therapy through dual COX-2/5-LOX inhibitors: A structure-based approach. Eur J Pharm Sci. 2018;121:356-381.

114. Weisman SM, Doyle MJ, Wehmeyer KR, Hynd BA, Eichhold TH, Clear RM, et al. Effects of tebufelone (NE-11740), a new anti-inflammatory drug, on arachidonic acid metabolism. Agents Actions, 1994;41: 156-163.

115. Ruiz J, Pérez C, Pouplana R. QSAR study of dual cyclooxygenase and 5-lipoxygenase inhibitors 2,6-di-tert-butylphenol derivatives. Bioorg Med Chem. 2003;11(19):4207-16.

116. Unangst PC, Connor DT, Cetenko WA, Sorenson RJ, Kostlan CR, Sircar JC et al. Synthesis and biological evaluation of 5-[[3,5-bis(1,1-dimethylethyl)- 4-hydroxyphenyl]methylene]oxazoles, thiazoles, and -imidazoles: novel dual 5-lipoxygenase and cyclooxygenase inhibitors with antiinflammatory activity. J. Med. Chem. 1994;37:322-328.

117. Inagaki M, Tsuri T, Jyoyama H, Ono T, Yamada K, Kobayashi M, et al. Novel antiarthritic agents with 1,2-isothiazolidine1,1-dioxide (gamma-sultam) skeleton: cytokine suppressive dual inhibitors of cyclooxygenase-2 and 5-lipoxygenase. J. Med. Chem. 2000;43:2040-2048

118. Hwang SH, Wecksler AT, Wagner K, Hammock BD. Rationally designed multitarget agents against inflammation and pain. Curr Med Chem. 2013;20(13):1783-99.

119. Ghatak S, Vyas A, Misra S, O'Brien P, Zambre A, Fresco VM, et al. Novel di-tertiary-butyl phenylhydrazones as dual cyclooxygenase-2/5-lipoxygenase inhibitors: synthesis, COX/LOX inhibition, molecular modeling, and insights into their cytotoxicities. Bioorg Med Chem Lett. 2014;24(1):317-24.

120. Lino RC, da Silva DPB, Florentino IF, da Silva DM, Martins JLR, Batista DDC, et al. Pharmacological evaluation and molecular docking of new di-tert-butylphenol compound, LQFM091, a new dual 5-LOX/COX inhibitor. Eur J Pharm Sci. 2017;106:231-243.

121. Hanwell MD, Curtis DE, Lonie DC, Vandermeersch T, Zurek E, Hutchison GR. “Avogadro: An advanced semantic chemical editor, visualization, and analysis platform". J Cheminform. 2012;4:17.

122. Frisch MJ, Trucks GW, Schlegel HB, Scuseria GE, Robb MA, Cheeseman JR, et al. Gaussian 09. Gaussian, Inc., Wallingford CT. 2009.

123. de Magalhães CS, Almeida DM, Barbosa HJC, Dardenne LE. A dynamic niching genetic algorithm strategy for docking highly flexible ligands. Inform. Sci. 2014;289:206-224. 
124. Laskowski RA, Swindells MB. LigPlot+: multiple ligand-protein interaction diagrams for drug discovery. J. Chem. Inf. Model. 2011;51:2778-2786.

125. Janusz JM, Young PA, Ridgeway JM, Scherz MW, Enzweiler K, Wu LI, et al. New cyclooxygenase2/5-lipoxygenase inhibitors. 1. 7-tert-buty1-2,3-dihydro-3,3-dimethylbenzofuran derivatives as gastrointestinal safe antiinflammatory and analgesic agents: discovery and variation of the 5-keto substituent. J Med Chem. 1998;41(7):1112-23.

126. Zheng M, Zhang Z, Zhu W, Liu H, Luo X, Chen K, et al. Essential structural profile of a dual functional inhibitor against cyclooxygenase-2 (COX-2) and 5-lipoxygenase (5-LOX): molecular docking and 3D-QSAR analyses on DHDMBF analogues. Bioorg Med Chem. 2006;14(10):3428-37.

127. Sali A. Comparative protein modeling by satisfaction of spatial restraints. Mol Med Today. 1995;1(6):270-7.

128. Misra S, Ghatak S, Patil N, Dandawate P, Ambike V, Adsule S, et al. Novel dual cyclooxygenase and lipoxygenase inhibitors targeting hyaluronan-CD44v6 pathway and inducing cytotoxicity in colon cancer cells. Bioorg Med Chem. 2013;21(9):2551-9.

129. Frisch MJ, Trucks GW, Schlegel HB, Gill PMW, Johnson BG, Robb MA, et al. GAUSSIAN 94, Rev. E.1; Gaussian Inc.: Pittsburgh, PA, 1995.

130. Sanz F, Manaut F, Rodríguez J, Lozoya E, López-de-Briñas E. MEPSIM: a computational package for analysis and comparison of molecular electrostatic potentials. J Comput Aided Mol Des. 1993;7(3):337-47.

131. Pommery N, Taverne T, Telliez A, Goossens L, Charlier C, Pommery J, et al. New COX-2/5-LOX inhibitors: apoptosis-inducing agents potentially useful in prostate cancer chemotherapy. J Med Chem. 2004;47(25):6195-206.

132. Revathi S, Gupta AK, Soni LK, Kavitha S, Wagh R, Kaskhedikar SG. Rationalization of physicochemical characters of 1,5-diarylpyrazole analogs as dual (COX-2/LOX-5) inhibitors: a QSAR approach. J Pharm Biomed Anal. 2006;42(2):283-9.

133. CS Chem Office, Version 8.0, Cambridge Soft Corporation, Software Publishers Association, 1730 M Street, Suite 700, Washington, DC 20036, USA.

134. Todeschini R, Consonni V. DRAGON-Software for the Calculation of Molecular Descriptors, rel. 1.12 for Windows, 2001.

135. Gupta AK, Babu MA, Kaskhedikar SG.VALSTAT: validation program for quantitative structure activity relationship studies. Indian J Pharm Sci. 2004;66:396-402.

136. Liaras K, Fesatidou M, Geronikaki A. Thiazoles and Thiazolidinones as COX/LOX Inhibitors. Molecules. 2018;23(3):685.

137. Geronikaki AA, Lagunin AA, Hadjipavlou-Litina DI, Eleftheriou PT, Filimonov DA, Poroikov VV, et al. Computer-aided discovery of anti-inflammatory thiazolidinones with dual cyclooxygenase/lipoxygenase inhibition. J Med Chem. 2008;51(6):1601-9.

138. Lagunin A, Stepanchikova A, Filimonov D, Poroikov V. PASS: prediction of activity spectra for biologically active substances. Bioinformatics. 2000;16(8):747-8.

139. Poroikov VV, Filimonov DA, Gloriozova TA, Lagunin AA, Druzhilovskiy DS, Rudik AV, et al. Computer-aided prediction of biological activity spectra for organic compounds: the possibilities and limitations. Russ Chem Bull. 2019;68:2143-2154. 
140. Kaur J, Bhardwaj A, Huang Z, Knaus EE. Aspirin analogues as dual cyclooxygenase-2/5lipoxygenase inhibitors: synthesis, nitric oxide release, molecular modeling, and biological evaluation as anti-inflammatory agents. ChemMedChem. 2012;7(1):144-50.

141. Mark A. ArgusLab version 4.0.1, Thompson Planaria Software LLC, Seattle, WA (USA).

142. Discovery Studio 3.0, Molecular Modeling Software, Accelrys Inc.

143. Misra S, Ghatak S, Patil N, Dandawate P, Ambike V, Adsule S, et al. Novel dual cyclooxygenase and lipoxygenase inhibitors targeting hyaluronan-CD44v6 pathway and inducing cytotoxicity in colon cancer cells. Bioorg Med Chem. 2013;21(9):2551-9. 


\title{
Metode kompjuterski potpomognutog dizajniranja lekova $u$ istraživanju novih potencijalnih terapeutika za neuropsihijatrijske i inflamatorne bolesti
}

\author{
Milica Radan, Jelena Bošković, Vladimir Dobričić, Olivera Čudina i \\ Katarina Nikolić*
}

Univerzitet u Beogradu - Farmaceutski fakultet, Katedra za farmaceutsku hemiju, Vojvode Stepe 450, 11000 Beograd, Srbija

Autor za korespodenciju: dr Katarina Nikolić, e-mail: knikolic@pharmacy.bg.ac.rs

\begin{abstract}
Apstrakt
Proces otkrića i razvoja lekova je veoma zahtevan, skup i dugotrajan. Veliki tehnološki napredak u molekularnoj biologiji i kompjuterskim naukama je omogućio primenu metoda kompjuterski potpomognutog dizajniranja lekova (CADD) u različitim fazama procesa otkrića i razvoja lekova. Danas CADD predstavlja efikasnu i nezamenljivu alatku, koja se široko koristi u medicinskoj hemiji za racionalni dizajn i sintezu novih jedinjenja. U ovom preglednom radu biće prikazani CADD pristupi koji se najčešće koriste od procesa identifikacije hit jedinjenja do optimizacije lead jedinjenja. Pored toga, biće predstavljeni različiti aspekti u dizajnu višeciljnih liganada za neuropsihijatrijske i inflamatorne bolesti. Pokazano je da su ova jedinjenja veoma efikasna u lečenju složenih bolesti zbog veće efikasnosti i manje neželjenih efekata koje izazivaju. Antipsihotici koji deluju preko aminergičnih G-protein spregnutih receptora (GPCR), posebno preko dopaminskih $\mathrm{D}_{2}$ i serotoninskih 5- $\mathrm{HT}_{2 \mathrm{~A}}$ receptora, predstavljaju najbolju opcija za lečenje različitih simptoma povezanih sa neuropsihijatrijskim poremećajima. Pored toga, dizajn i sinteza dualnih inhibitora ciklooksigenaze-2 (COX-2) i 5- lipoksigenaze (5-LOX) takođe predstavlja uspešan pristup u otkrivanju novih antiinflamatornih lekova sa manje neželjenih efekata. Na kraju se može zaključiti da primena CADD metoda u procesu racionalnog dizajniranja lekova pruža značajnu priliku za dalji napredak jer omogućava brzu identifikaciju jedinjenja sa optimalnim polifarmakološkim profilom.
\end{abstract}

Ključne reči: CADD, 5-HT2A, D2, COX-2, 5-LOX 